\title{
1 Fracture abundance and strain in folded Cardium Formation, Red Deer River 2 anticline, Alberta Foothills, Canada
}

Estibalitz Ukar, Canalp Ozkul, and Peter Eichhubl

Estibalitz Ukar (corresponding author)

Bureau of Economic Geology

Jackson School of Geosciences

The University of Texas at Austin

University Station Box X, Austin, TX 78713-8924, USA

Tel: (512) 471-2764

Cell: (512) 797-2639

Fax: (512) 471-0140

E-mail: esti.ukar@beg.utexas.edu

\section{Canalp Ozkul}

Bureau of Economic Geology

Jackson School of Geosciences

The University of Texas at Austin

University Station Box X, Austin, TX 78713-8924, USA

Peter Eichhubl

Bureau of Economic Geology

Jackson School of Geosciences

The University of Texas at Austin

University Station Box X, Austin, TX 78713-8924, USA

Tel: (512) 475-8829

Fax: (512) 471-0140

E-mail: peter.eichhubl@ beg.utexas.edu 
36 The folded and thrusted Mesozoic clastic sequence of the Canadian Rocky Mountain foothills

37 forms important hydrocarbon reservoirs; however, the generation of fractures and their timing 38 relative to folding and thrusting have remained unclear. Understanding the distribution and 39 evolution of natural fractures, especially their timing of formation relative to the evolution of the 40 fold-and-thrust system, could potentially improve exploration and development outcomes in 41 these otherwise tight, low-permeability reservoirs. We investigated the relation between folding 42 and fracture formation in the Upper Cretaceous Cardium Formation by combining field structural 43 observations and kinematic modeling of the fold-and-thrust belt evolution. We evaluated the 44 effects of structural position and strain on the formation of predominantly opening-mode 45 fractures by analyzing fracture intensity and aperture in the backlimb, the shallow forelimb close 46 to the crest, and the steep forelimb, away from the crest of a reservoir-scale anticline, the Red 47 Deer River anticline. Fracture strain determined from both outcrop and microscanlines varies 48 little across the three structural domains of the fold, although somewhat lower fracture strain was 49 measured in the forelimb close to the crest. These fracture strain measurements are qualitatively 50 consistent with calculated horizontal strain in the tectonic-transport direction obtained from 51 kinematic numerical models that simulate fold development associated with slip along the 52 underlying Burnt Timber thrust. The kinematic models predict similar magnitudes of horizontal 53 extension in both the back and forelimbs, and somewhat lower extension in the upper forelimb 54 during early development of the Red Deer River anticline. Predicted early fracture formation 55 during fold development is consistent with field structural observations of shear reactivation 56 during later stages of folding. This combined kinematic modeling and field structural study 57 demonstrates that deforming fold and thrust belts can undergo a complex evolution of bed58 parallel extension in both space and time, resulting in spatially variable fracture formation in 59 structurally complex subsurface reservoirs.

60 Keywords: Cardium; Alberta Foothills; Fracture abundance; Strain 


\section{INTRODUCTION}

62 The Canadian Rocky Mountains are one of the most extensively studied foreland fold63 and-thrust belts, with specific focus on the Foothills and Front Ranges because of their 64 hydrocarbon potential (Leckie and Smith, 1992; Price, 1994; Boettcher et al., 2010). The 65 Foothills of the Canadian Rocky Mountains have been explored for oil and gas since the early $6620^{\text {th }}$ century. Initially, exploration primarily focused on what are now termed conventional 67 hydrocarbon reservoirs, but the low-permeability hydrocarbon reservoirs have been the focus in 68 recent years. Since natural fractures affect permeability, and thus production from these tight 69 reservoirs, an understanding of the spatial distribution of natural fractures, their structural and 70 diagenetic attributes, and the spatial and temporal relationships of their formation relative to the 71 fold-and-thrust belt evolution are important (Currie and Nwachukwu, 1974; Currie and Reik, 72 1977; Narr and Currie, 1982; Newson, 2001; Salvini and Storti, 2001; Jager, 2008). However, 73 the spatial and temporal relationships between fracture formation and the development of folds 74 and thrusts based on field structural criteria are frequently ambiguous. For example, folds in 75 fold-and-thrust belts may undergo a complex evolution, with regions of highest curvature and 76 folding-induced strain migrating in space and time (e.g., Salvini and Storti, 2004), making it 77 difficult to reconstruct the conditions under which fractures formed relative to the fold geometry 78 observed in outcrop or seismic profiles.

79 Production rates in the Cardium Formation are regionally variable (e.g., Van and Pedersen, 80 2015), which may be related, at least in part, to regional differences in natural fracture 81 characteristics. Moreover, well tests, flow rates, and production flow surveys that are 82 incompatible with production from the rock matrix alone have convinced operators in western 83 Canada that natural fractures contribute to production (e.g., Cooper, 1992; Jamison, 1997; 
84 Newson, 2001; Solano et al., 2011). However, uncertainty about where and when fractures form 85 relative to the fold-and-thrust belt regional structure means that the location of abundant, open 86 fractures cannot be accurately predicted. This leads to unacceptable risk in exploration and 87 development decisions (Nelson, 1985; Newson, 2001)

Formation of fractures related to folding was conceptualized several decades ago (Price 89 1966; Stearns, 1968; Friedman, 1969; Stearns and Friedman, 1972; Hancock, 1985; Price and 90 Cosgrove, 1990), and many recent studies have inferred fracture formation related to folding in 91 fold-and-thrust belts (Hennings et al., 2000; Hanks et al., 2004; Florez-Niño et a., 2005; 92 Bellahsen et al., 2006; Tavani et al., 2006, 2008; Ghosh and Mitra, 2009; Smart et al., 2012). 93 However, fractures can also predate folding and potentially become reactivated in opening-mode 94 or by shearing during folding (Dunne 1986; Laubach, 1988; Bergbauer and Pollard, 2004). 95 Reactivation also leads to formation of new fractures (Davatzes and Aydin, 2003). Furthermore, 96 fractures may form during uplift and exhumation concurrently with, or after, folding and 97 thrusting (Currie and Reik, 1977; Engelder, 1985; Casini et al., 2011; English, 2012; Reif et al., 98 2012; Fall et al., 2012, 2015). Fractures formed during later stages of exhumation may not be of 99 significance to deep petroleum reservoirs.

Interpretation of fracturing associated with folding may be hindered by lack of direct observation of the changes in fracture patterns through time within an evolving fold-and-thrust sequence unless fracture cementation is syntectonic - during deformation- and all deformational stages are recorded. Previous studies that addressed the spatial and temporal relationships between fracture formation and fold-and-thrust development were based on 1) field observations of crosscutting relationships between fractures, folds, and associated structures such as stylolites (Muecke and Charlesworth, 1966; Nickelsen, 1979; Barton, 1983; Graham et al., 2003), 2) 
comparison of numerically modeled folds and natural folds with syn-tectonic growth strata (Verges et al., 1996; Ford et al., 1997; Poblet et al.,1997; Novoa et al., 2000; Salvini and Storti, 2002; Shackleton et al., 2011), 3) structural restoration algorithms (Rouby et al., 2000; Griffiths et al., 2002; Thibert et al., 2005; Maerten and Maerten, 2006), and 4) forward geometric and geomechanical fold models (Erslev, 1991; Johnson and Johnson, 2002; Poblet and McClay, 1996; Suppe, 1983; Suppe and Medwedeff, 1990; Smart et al., 2012). We combine field-based observations of cross-cutting relationships with forward kinematic models to show that fractures either predate or formed at the onset of folding, and subsequently evolved during continued thrusting and folding.

In this study, we document relative timing and spatial distribution of fractures in a reservoir-scale fold, the Red Deer River anticline, Alberta, Canada (Figure 1). Fractures are observed in the Cretaceous Cardium Formation, a sandstone with low porosity and permeability that is a significant reservoir in the Alberta Foothills. By comparing observed fracture distributions to the modeled evolution of this fault-related fold, we test whether fractures are kinematically related to folding or pre- or postdate folding. This study combines (i) field investigations to analyze fracture characteristics such as aperture and cement fill within a structural context, (ii) macro- and microscanline analyses to measure fracture abundance and strain within structural position, and (iii) kinematic models to both constrain the timing of fracturing in the Foothills relative to the overall structural evolution of the fold-and-thrust belt in this area, and to compare strain distributions from the models to those measured using scanlines in the field. If fractures formed concurrently with folding, fracture abundance is expected to correlate with folding-associated strain. Alternatively, if fractures formed prior to or postfolding, no correlation between fractures and folding strain is expected. A comparison between 
130 field fracture strain data and strain calculated by numerical fault and fold kinematic models 131 indicates that 1) opening-mode fractures within the Cardium Formation in the Red Deer River 132 anticline either predate folding or formed during the early onset of folding, and 2) cross-fold, opening-mode fractures were reactivated in shear and linked through propagation during folding.

\section{GEOLOGIC SETTING}

The Red Deer River anticline is located in the central portion of the Alberta Foothills that form the eastern part of the Rocky Mountains, a thin-skinned, Late Jurassic to Eocene foreland fold-and-thrust belt (Monger, 1989) (Figure 1). The structural framework of the Alberta Foothills contains numerous steeply-dipping, northeasterly-verging imbricate thrust sheets of the Mesozoic foreland basin and eastward-tapering sedimentary wedge rocks that were deposited on the North American crystalline basement (Price, 1994; Fermor, 1999). During the Paleozoic era, marine carbonates, shales, and sandstones were deposited along the western margin of North America. In contrast, lower Jurassic to Paleogene rocks comprise sandstone, siltstone, conglomerate, and shales that were deposited in the foreland basin during the rise of the Canadian Cordillera (Bally et al., 1966; Price, 1973; Beaumont, 1981; Stockmal et al., 1992). The deformation history in the Canadian Rocky Mountains is characterized by northeastward shortening during the Laramide orogeny from Campanian to Eocene time (Price, 1994, Eisbacher et al., 1974; van der Plujim et al., 2006), although there is evidence that deformation east of the Rocky Mountain Trench began as early as Late Jurassic (e.g., Pana and van der Plujim, 2015).

The mechanical contrast between Paleozoic and Mesozoic rocks exerts a strong control on the deformation style of the orogen (Price, 1981; Taerum, 2011).

The clastic succession of Mesozoic rocks includes the prominent Upper Cretaceous Alberta Group. This group consists of predominantly marine to coastal marine foreland basin 
153 fills (Stott, 1963) (Figure 2). A prominent sandstone unit of this group is the Cardium 154 Formation, which separates thick sections of shale of the Wapiabi Formation above and the 155 Blackstone Formation below the Cardium. It has been proposed that these thick shales 156 mechanically decouple the Cardium Formation from deformation in the overlying and 157 underlying competent units (Wall, 1967; Taerum, 2011). The Cardium Formation is 158 approximately $150 \mathrm{~m}$ thick where exposed in the central Alberta Foothills, and highly variable 159 but around $50 \mathrm{~m}$ thick in the subsurface under the Plains to the east (Krause et al., 1994). The 160 Cardium Formation contains large hydrocarbon reserves east of the Foothills, where it is forming 161 the youngest oil-bearing formation and it is also a major producer in the Pembina field southwest 162 of Edmonton (Krause et al., 1994; Newson, 2001).

\section{Cardium Formation of the Red Deer River Anticline}

We investigated fracture distribution within the Cardium Formation exposed on the slopes of the Red Deer River valley across from the Mountain Aire Lodge west of Sundre, Alberta, Canada (Figure 3). The Cardium Formation is exposed for about $1 \mathrm{~km}$ along a section oriented approximately perpendicular to the axis of the NW-plunging Red Deer River anticline (Olleranshaw, 1996; Dechesne and Veilleux, 2000). Bedding dip varies from approximately 25$30^{\circ} \mathrm{W}$ in the western limb to $35-40^{\circ} \mathrm{E}$ in the eastern limb, and average approximately $50^{\circ} \mathrm{E}$ in the easternmost part of the east limb. The strata forming the crest of the anticline are not exposed. The Cardium Formation in the study area is composed of very fine to medium-grained, gray to dark gray-brown sandstone layers. The sandstones exhibit differing types of internal lamination, including hummocky cross-stratification and varying amounts of bioturbation. In the Red Deer River anticline, the Cardium Formation can be subdivided into three members from the base to the top: the Kakwa, Low Water, and Karr members, each of which is separated by finer-grained, 
177 The classification of members at this locality is based upon similarity in stratigraphic position 178 relative to the Musreau/Kakwa delta succession to the northwest (Plint et al. 1988). The three 179 members of the Cardium Formation are well-exposed on the west and east limbs of the Red Deer 180 River anticline on the hillside, and in two smaller outcrops (Figure 3) located on the north and 181 south banks of the Red Deer River adjacent to the Mountain Aire Lodge. We divided the Red 182 Deer River anticline into three structural domains. The west limb of the anticline is hereafter spans the shallow part of the east limb near the eroded hinge, and Domain III spans the more steeply dipping part of the east limb (Figure 3a).

The Kakwa Member is most completely exposed on the western limb of the fold (Domain I) and it consists of well-developed upper and lower parts. Both horizons are thinner -or less completely exposed- in the east limb of the fold (Domain II) to the point that the lower portion of the Kakwa is not visible from a distance. The overlying Low Water Member displays approximately constant thickness along the $1 \mathrm{~km}$-wide exposure, and is both finer-grained and more highly bioturbated than the Kakwa Member. The uppermost Karr Member shows the greatest variability; on the west limb it is composed of thinner, amalgamated, hummocky crossstratified, upper flow regime sandstone incised into thicker bioturbated, fine-grained muddy silty turbidites; on the east limb it is composed of very fine- to fine sandstone with planar to hummocky cross-stratified bed forms. Domain III comprises the most steeply-dipping part of the east limb, which outcrops on the hillside and along a small exposure located on the south side of the Red Deer River (Figure 3f-g). This small exposure is inferred to be part of the Kakwa Member based on lithological properties and stratigraphic/structural location. 
All samples analyzed are fine-grained litharenites containing on average $15-20 \%$ chert

200

201 and $10-15 \%$ mud clasts. Bioturbated litharenites of the Kakwa Member comprise up to $30 \%$ mud clasts. Monocrystalline quartz grains are more sutured within the planar-laminated and crossstratified Kakwa and Karr sandstones, versus the bioturbated Kakwa sandstone. Karr litharenites contain up to $5 \%$ intergranular porosity in these exposures, whereas porosity in the Kakwa sandstones is nearly zero.

\section{FRACTURE CHARACTERIZATION}

\section{Methods}

To quantify the extensional strain accommodated by opening-mode fractures in the direction of tectonic transport, we measured fracture aperture and spacing within the Cardium Formation in the direction perpendicular to the trend of the Red Deer River anticline along one dimensional scanlines in the field and in thin section. Because only extension parallel to the tectonic transport direction was modeled in this study, one dimensional scanlines oriented parallel to the transport direction, measuring the strain tensor component parallel to the one dimensional scanline, was considered adequate. To avoid inclusion of fractures that formed during late-stage exhumation and thus potentially unrelated to folding, we measured spacing and aperture only of completely cemented or cement-lined fractures. We will demonstrate below that fracture cements formed during fracture opening under deep burial conditions unlike barren fractures that are assumed to form during late-stage exhumation. Barren fractures were not included in the scanlines.

For each fracture measured in outcrop, we recorded kinematic aperture (distance orthogonal to the fracture from one fracture wall to the opposite wall, counting cement infill and remaining fracture porosity as fracture aperture, fracture spacing, and cement infill typet. 
222 Fracture aperture was measured using a hand lens against an aperture comparator as described by

223 Ortega et al. (2006) We refer to the scanlines measured in the field as macroscanlines, and 224 fractures $\geq 0.1 \mathrm{~mm}$ in aperture as macrofractures. were collected from three lithologically different layers within the Kakwa Member in the 
245 steepest part of the forelimb (Domain III), and two samples were collected from lower and upper 246 portions of the Kakwa Member on the back limb near the crest of the anticline (Domain I). 247 Fracture strain calculations using macro- and microfractuare data are explained below.

248 In sum, fracture scaling analyses were performed on two macroscanlines and 38 249 microscanlines from eleven field samples.

For microscanlines, we prepared contiguous polished thin sections from field samples following the method described by Gomez and Laubach (2006). Microscanline length ranged from 2.6 to $25.8 \mathrm{~cm}$. Thin sections were imaged with an Oxford MonoCL cathodoluminescence (CL) system attached to a Philips XL30 SEM at the Bureau of Economic Geology, The University of Texas at Austin. Operating conditions were at $15 \mathrm{kV}$ using a blue filter, and CL images were assembled into contiguous mosaics following the protocol described by Gomez and Laubach (2006) and Hooker et al. (2015). CL images provide information about fractures that are not discernible with the naked eye or using transmitted light petrography (Milliken and Laubach, 2000). CL images were imported into Didger 3 digitizing software where fractures were spatially referenced. Spatial X-Y coordinates generated by Didger 3 were imported into an Excel routine that allows for the calculation of fracture aperture, spacing, and other fracture statistics based on spatial coordinates (Gomez and Laubach, 2006). Only transgranular fractures were selected, and fractures were then subdivided into sets based on their orientation and systematic cross-cutting relationships.

\section{Fracture orientations}

\section{Opening-mode fractures}

We distinguish four sets of bed-perpendicular, opening-mode fractures based on 
268 All bed-perpendicular but set 4 are bed-bounded, i.e., fractures terminate against bedding 269 surfaces or are confined within a bed (Table 1). In the classification of Hooker et al. (2013) the 270 height pattern is top-bounded on the scale of individual beds, but with a hierarchical pattern of 271 more widely spaced fractures that cut several beds. Set 1 fractures are sub-perpendicular to the 272 fold axis (cross-fold), set 2 fractures are oblique to the fold axis (cross-strike), and set 3 are 273 subparallel to the fold axis (strike-parallel) (Figure 4). In Domain I, set 1 fractures strike roughly 274 N-S, set 2 fractures strike NW-SE, and set 3 fractures strike E-W (Figure 5a). In Domains II and 275 III, the relative orientations are preserved, but all fracture sets rotate progressively clockwise by $27640-60^{\circ}$ consistent with the change in bedding across the fold. When bedding is rotated to 277 horizontal, fractures of all bed-perpendicular sets show similar orientations across the different 278 structural domains of the fold (Figure 5b).

279 Set 4 fractures, several meters tall, cut the sandstone layers of the Kakwa Member from 280 top to bottom (Figure 6a, c), and are best developed within Domain II. Although of the same 281 orientation as set 1 fractures, these through-going set 4 fractures are interpreted as a separate set 282 because they are closely spaced (meters), occur in clusters, several meters tall, and are not 283 stratabound in specific sandstone beds. Many set 4 fractures show evidence of reactivation in 284 shear with both strike and dip senses of movement. For both types of reactivated set 4 fractures, 285 shear reactivation is evidenced by wing cracks (Figure 6b). Offset bedding planes indicate bed286 normal displacements ranging from $1-13 \mathrm{~cm}$. A few set 4 fractures have subhorizontal striations 287 indicating a strike-slip sense of shear. Linkage patterns by oblique segments exposed along 288 pavements within Domain III are also compatible with strike-slip shear. Therefore, set 4 289 fractures seem to have formed by linkage and propagation of set 1 fractures, and were 
290 subsequently reactivated in both strike-slip and dip-slip motion.

$291 \quad$ Faults

292 Although bedding-perpendicular, opening-mode fractures are the most common fracture 293 type in these outcrops, faults with striated surfaces are also present in all three domains (Figure 294 6c, d). Low-angle thrust faults are abundant, their orientation varying with structural position 295 (Figure 6d-f). A few faults that shorten bedding cut bedding at a steeper angle, and such high296 angle reverse faults are best seen in Domain III along the southern bank of the river. Fault 297 kinematics of thrust and reverse faults are compatible with SW-NE shortening, perpendicular to 298 the fold axis.. Bedding-parallel slip surfaces are abundant on the hillside outcrops and most 299 likely indicate flexural slip; such faults could form as a results of folding.

300 Cross-cutting relationships and relative timing

301 Consistent cross-cutting relationships between different fracture sets indicate that set 2 302 fractures cut set 1, and that set 3 cuts both set 1 and set 2 (Figure 7). Thus, set 1 fractures are the 303 oldest and set 3 are the youngest of these three opening-mode fracture sets. Set 4 fractures are 304 inferred to be younger than set 1 based on the differences noted above and because their location 305 within fracture clusters and prevalence of slip surfaces suggest that they formed by reactivation 306 and linkage of set 1 fractures. Fault kinematics of bedding-parallel faults, thrust and reverse 307 faults, and slip along set 4 fractures are compatible with the expected kinematics of folding 308 (Figure 6d). Set 4 fractures cut or abut against low-angle thrust faults, and low-angle faults do 309 not displace the blocks cut by set 4 fractures, indicating that set 4 postdates low-angle thrust 310 faults (Figure 6b). Propagation and linkage that led to the formation of set 4 fractures is thus 311 inferred to have occurred during folding, and reactivation in shear along set 4 fractures is the 
312 youngest event. Due to a lack of observed cross-cutting relations, the relative timing of set 5 is 313 unknown.

\section{$314 \quad$ Fracture cements}

315 Quartz is the most common and most abundant fracture cement in all fracture sets, 316 although some of the fractures also have minor calcite cement (less than 10\%). Most of the 317 microfractures and narrow macrofractures are completely filled with quartz cement, yet some of 318 the wider fractures preserve traces of primary porosity up to $\sim 7 \%$ of the fracture volume 319 (Figures 7a, c). Narrow fractures exhibit crack-seal texture (Figure 7b, d) that indicates quartz 320 cement precipitation concurrent or synkinematic with fracture opening (Ramsay, 1980; Laubach, 321 1988). In wider fractures $(>\sim 0.15 \mathrm{~mm})$, crack-seal texture is restricted to fracture margins 322 (Figure 7a, c).

$323 \quad$ Fluid inclusion analyses of fracture quartz from one set 3 fracture within the inferred 324 upper portion of the Kakwa Member in Domain III reveals primary two-phase inclusions 325 containing a hydrocarbon liquid and a gas phase. Homogenization temperatures of these 326 inclusions range from $69^{\circ} \mathrm{C}$ to $124^{\circ} \mathrm{C}$. These temperatures are minimum estimates of trapping 327 temperatures and of fracture cement precipitation, confirming the deep-burial conditions of 328 quartz precipitated within set 3 . These temperature estimates are in accordance with temperatures 329 in excess of $80{ }^{\circ} \mathrm{C}$ required for fast accumulation of quartz cement (Walderhaug, 1994, 1996).

330 The presence of synkinematic quartz cement in fractures in the study area indicates these 331 fractures were opened and cemented deep in the subsurface and not at near-surface conditions.

\section{Fracture abundance}

333 Along a one dimensional line of observation (scanline), fracture intensity is defined here 
335 frequency of kinematic aperture indicates aperture-size rank (i.e. 1 is the widest fracture, 2 is the 336 second widest, etc.) divided by scanline length, and kinematic aperture indicates the width of the 337 fracture (Marrett, 1999; Ortega et al., 2006) (Figure 7). Cumulative frequency has units of 338 number of fractures per unit length, thus its inverse is the average spacing of the fractures. 339 Because the data are normalized (scanline length is taken into account) for different locations, 340 scanline lengths and fracture apertures are directly comparable (Ortega et al., 2006).

344 smallest apertures (truncation), and the largest scales of observation (censoring) (see Hooker et 345 al., 2015 for discussion of truncation and censoring in fracture aperture distributions). A general 346 scarcity of data representing fractures with apertures between $0.01-0.1 \mathrm{~mm}$ in these scanline data 347 may reflect an observation gap between data collected in outcrop (macrofractures) and through 348 SEM imaging (microfractures). In most data sets in this study, the narrowest microfractures can 349 be fitted by a power-law distribution that has a steeper slope than that of the medium-sized 350 fractures (Figure 8a). The slope of the narrowest microfractures ranges between -0.5 and -4.2 351 (most are between -0.9 and -2.8), whereas that of the medium-sized fractures ranges between 3520.2 and -0.8 (most are between -0.2 and -0.5 ). Intensities (y axis) of the narrowest microfractures 353 show a range of up to 1 order of magnitude for the same fracture set within the same domain. In 354 contrast, the intensity of medium-sized fractures is similar and well constrained in each case. For 355 example, the intensity of $0.1 \mathrm{~mm}$ aperture fractures is $\sim 0.02-0.04$ fractures $/ \mathrm{mm}$, irrespective of 356 the fracture set or structural position (Figure 8a). The two field samples collected along scanline 

1 (RD-1 and RD-5) show similar intensities of the narrowest microfractures for both set 1 and set 3.

Because of the outcrop orientation, the two macroscanlines measured in Domains I and II contain predominantly set 1 fractures. Extrapolation of power-laws fitted through the narrowest 361 set 1 microfracture data in these two domains is not a good predictor of the intensity of 362 macrofractures, probably because the steep slopes of the narrowest microfractures are not 363 maintained for fractures wider than about $0.01 \mathrm{~mm}$ (Figure 8). Based on a large dataset, Hooker 364 et al. (2015) found that, in many cases, fitting a slope of -0.8 to measured microfracture data can 365 predict the abundance of macrofractures to a first approximation. Both field samples collected 366 along scanline 1 show overlapping intensities for the narrowest microfractures if the data 367 affected by truncation bias are excluded. If we extrapolate the abundance of macrofractures from 368 the narrowest microfractures using a slope of -0.8 , we obtain a reasonably good prediction for 369 macrofracture abundance in this part of the fold (Figure 8a). For scanline 2, this method 370 provides estimates of fracture intensity good to within half an order of magnitude.

\section{Effect of lithology on fracture intensity}

372 To evaluate the effect of lithology on fracturing in the Cardium Formation, we examined 373 the fracture intensities of three adjacent samples from three different lithological units within the 374 Kawka Member of Domain III: 1) a bioturbated layer-sample CO-14-3, 2) a planar-laminated 375 layer -sample CO-14-2, and 3) a hummocky cross-stratified layer -sample CO-14-1, as well as 376 samples from the planar-laminated upper (CO-15-2) and bioturbated lower (CO-15-1) portions 377 within the Kakwa Member of Domain I (Figures 3 and 8b). These samples were cut in two 378 orthogonal orientations to capture the three main fracture sets. Fracture intensities of the same 379 fracture set differ to within half an order of magnitude in different lithologies. For example, the 
380 intensity of set 1 fractures in Domain III is higher in the planar-laminated layer than in the 381 bioturbated and hummocky cross-stratified layers. This same distribution is found in the lower 382 and upper portions of the Kakwa Member within Domain I.

383 Most of our measurements were made in layers of similar thickness. The exceptions were 384 the lower and upper portions of the Kakwa in Domain I, where the thickness of the bioturbated 385 lower Kakwa package (considered one layer) is similar to that of the planar-laminated upper 386 Kakwa (tens of layers). Our data show no correlation between fracture abundance and layer 387 thickness because layers of similar thicknesses (i.e. Domain III lithologies; Figure 8b) have 388 different fracture intensities. Thus, we infer that bioturbation is more important than layer 389 thickness on governing fracture abundance in the Cardium Formation. The correlation we found 390 of fracture intensity with rock type holds for fractures in different orientations, but fracture 391 abundance may be higher or lower depending on which orientation is considered. Lithological 392 differences in clay content and distribution could be responsible for the observed within-sample 393 (cm-to m-scale) variability in abundance of the narrowest microfractures.

\section{$394 \quad$ Fracture strain}

\section{$395 \quad$ Strain Analysis Methods}

396 We measured the strain accommodated by opening-mode fractures in the direction 397 parallel to the cross section (roughly perpendicular to the fold axis) using two methods. In 398 method 1, fracture strain $\varepsilon$ is defined as a measure of the extension along a one dimensional line 399 of observation (the scanline):

$$
\varepsilon=\frac{L-L_{0}}{L_{0}}=\frac{\sum \text { Aperture }}{\sum \text { Spacing }}
$$


where $\mathrm{L}$ is the final length and $\mathrm{L}_{0}$ is the initial length. Using this method, fracture strain equals 401 the sum of all apertures divided by the sum of all spacings. To avoid counting fractures that were 402 contained in both micro- and macroscanline datasets, fracture populations in microscanlines were 403 truncated at apertures $>0.1 \mathrm{~mm}$ and in macroscanlines at apertures $\leq 0.1 \mathrm{~mm}$. Fracture strain for 404 each location was calculated as the sum of strain recorded by fracture sets 1-3 observed in the 405 field.

406 In method 2, strain is calculated as an aggregate strain estimate based on fracture 407 frequency versus aperture plots (Figure 7) following Marrett et al. (1992) and Marrett (1996):

409 where $\zeta$ is the Rieman zeta function, $b$ is the slope of the power-law distribution function, $D_{\max }$ is 410 the maximum fracture aperture, and $f_{\max }$ is the fracture frequency of $D_{\max }$. Following Marrett 411 (1996), $\zeta$ is approximated by:

$$
\zeta(\mathrm{x}) \cong 1+2^{-x}+3^{-x}+\frac{x+7}{2(x-1)} 4^{-x}
$$

412 For strain calculations using method 2 we assumed a constant slope of -0.8 , and used 413 power-law distributions fitted through the narrowest microfractures. Fitting a slope of -0.8 414 through microfractures results in good predictions of macrofractures in our dataset, and can help 415 overcome strain biases derived from undersampling of macrofractures in scanlines of limited 416 length.

\section{$417 \quad$ Strain Results}

418 Strain calculated via method 1 using microfractures $<0.1 \mathrm{~mm}$ in aperture ranges between $4191.17 \times 10^{-3}$ and $9.39 \times 10^{-3}$, whereas strain calculated using macrofractures $>0.1 \mathrm{~mm}$ in aperture is 
$420 \sim 6.7 \times 10^{-3}$ for both macroscanlines. Strain calculated using method 2 ranges between $5.3 \times 10^{-3}$ and $4213.2 \times 10^{-2}$ when $D_{\max }$ is $0.1 \mathrm{~mm}$, and $8.4 \times 10^{-3}$ and $5.2 \times 10^{-2}$ when $D_{\max }$ is $1 \mathrm{~mm}$ (Table 3). Fracture

422 strain shows no consistent variation with structural position in the fold, i.e. although strain magnitudes vary depending on the calculation method, relative strain values are similar across the fold regardless of structural position (Figure 9; Table 3). For example, fracture strain in the planar-laminated Kakwa Member is higher in the steeper dipping Domain III than in Domain I, but fracture strain for the Karr Member is higher in Domain I compared to Domain III. The large range in fracture strain within the Kakwa Member of Domain II suggests that local variations in fracture strain are larger than variations among different domains of the fold. Variations between different lithologic units of the same member in the same domain are equally large.

\section{KINEMATIC MODEL AND STRAIN DISTRIBUTION}

In the Red Deer River area, the spatial and temporal relationships between fractures and complex, seismic-scale structures (folds, faults) remain ambiguous. Geometrically valid framework models that adhere to geologic principles can be used to explain both the relationship of deformational components and their evolution throughout the deformation. For example, opening-mode fractures may accommodate bed-parallel, outer-arch extension associated with folding, resulting in a correlation between folding strain and fracture strain (Beekman et al., 2000; Tavani et al., 2014). In our study, we constructed kinematic models to 1) validate the structural interpretation of regional structures, 2) explore possible deformation styles that could have produced present-day structures, and 3) calculate bed-parallel extension in the tectonic transport direction during development of the fold-and-thrust belt. These strain calculations serve as a basis for predicting fracture strain associated with this deformation. Predicted strain distribution and timing relative to fold-and-thrust development were then tested by comparing 
retrodeformed model is thus a pseudo-3D model. The evolution of the Red Deer River anticline was subsequently modeled from the original starting point with horizontal bedding to the present-day structural geometry through progressive stages of faulting that proceeded from the hinterland to the foreland (Figures 12 and 13).

Due to limitations in available algorithms in Move 3D, we were not able to implement flexural slip as a deformation mechanism. Moreover, Move does not take into account layer thickness for strain calculations. In order to avoid differences in strain that would result from higher outer-arc than inner-arc extension we chose layers of similar thickness that are at comparable stratigraphic levels on both limbs of the anticline for strain analysis. During forward modeling, strain tensors were calculated for the top of the Cardium Formation using Move's strain tool. The strain calculated by this tool results from displacements imposed on the layer of interest by the thrust-and-fold development in the underlying units. No strains are imposed on the lateral boundaries of the model. Currently, Move does not isolate the elongation parallel to bedding and thus orthogonal to fractures oriented perpendicular to bedding but it calculates strain in terms of principal strain directions. Because bedding generally dips less than $45^{\circ}$, fractureopening strain was measured using the horizontal strain component $\mathrm{e}_{\mathrm{xx}}$, and strain was calculated for both incremental steps and cumulative cases (Figures 12 and 13).

\section{Strain patterns and magnitudes from models}

\section{Distribution of Incremental Maximum Horizontal Elongation $e_{x x}$}

Magnitudes of the maximum horizontal elongation $\mathrm{e}_{\mathrm{xx}}$ were calculated for multiple stages of displacement along each fault relative to the previous stage of deformation, i.e. resetting the strain to zero after each deformation stage. Strain from earlier stages is thus not included in the strain of the following deformational stage in Figure 12. Displacement along fault 5 is relatively 
small and does not affect the strain distribution around the eventual location of the Red Deer River anticline (Figure 12a). Fault 4 is a blind fault that does not cut through Cardium strata. Instead, strata above this fault are passively moved, and this displacement causes the highest $\mathrm{e}_{\mathrm{xx}}$ strain to be concentrated around the future location of the Red Deer River anticline at this stage (Figure 12b).

cross section) is relatively large and has been subdivided into several steps. This fault is a splay off a larger structure at depth, the Blue Hills thrust, which displaces the Paleozoic section with a displacement on the order of $\sim 25 \mathrm{~km}$ (Peter Fermor, personal communication). During the early stage of deformation along the Burnt Timber thrust, high elongation areas are located in the limbs of the evolving Red Deer River anticline (Figure 12b), but as displacement continued, the locations of high and low strain concentrations changed. High strain (indicated by red) subsequently decreased (blue colors) as the layer passed through the anticline and flattened into the forelimb (Figures 12c-e). Elongation is concentrated in the forelimb of the Red Deer River anticline in stage $\mathrm{c}$, and in the backlimb during stage d. As deformation progresses, the highest elongation is consistently concentrated near the deformation front, whereas strain around the evolving Red Deer River anticline is highly variable throughout the deformation. Displacement along faults 2 and 1 resulted in elongation east of the Red Deer River anticline in the layers above the James River anticline, which is now largely eroded, while the Red Deer River anticline itself remained relatively undeformed (Figures 12f-h). These models predict that most of the horizontal elongation experienced by the Cardium Formation in the Red Deer River anticline occurred in the early stages of displacement along fault 3, with a pronounced phase of extension in the backlimb of the Red Deer River anticline during stage d (Figure 12d). 


\section{Distribution of Cumulative Horizontal Elongation $e_{x x}$}

Cumulative maximum horizontal elongation was calculated for stages a through $\mathrm{h}$ in 514 Figure 13 by adding together all strain increments relative to the initial undeformed state. Thus, each stage represents the cumulative strain the rock has experienced. Similar to the noncumulative strain case, displacement along fault 3 caused the highest elongation to initially occur in both limbs of the Red Deer River anticline (Figure 13b), and further displacement along this fault resulted in elongation of the backlimb of the Red Deer River anticline (Figure 13c). As displacement continued along fault 3, areas that were highly elongated developed into lowerstrain areas, indicating that both originally-elongated strata underwent shortening as deformation progressed and that folded layers flattened out as they migrated through the fold hinge (Figure 13d-e). The relatively small displacement along fault 2 did not have any noticeable effect on the strain distribution of Cardium strata (Figure 13f), whereas slip along fault 1 caused elongation of the Cardium strata to the east of the Burnt Timber thrust above the James River anticline (Figure 13g-h).

Therefore, the forelimb of the Red Deer River anticline undergoes a distinct phase of cumulative extension during stage c. From stage d onward, somewhat higher elongation is observed in the backlimb (green colors) compared to the forelimb (blue colors) of the Red Deer River anticline. This difference is less than 0.1. Within the forelimb, somewhat lower strains are observed toward the crest, and higher strains toward the trough of the Red Deer River syncline which is located east of the anticline. The final cumulative strain distribution shows slightly larger elongation in the backlimb of the Red Deer River anticline than in the forelimb, but cumulative strain magnitudes are similar on both limbs. The areas of highest elongation are located in the now eroded Cardium Formation east of the Red Deer River anticline. 


\section{DISCUSSION}

Dechesne and Villeaux (2000) identified three main sets of fractures in the Red Deer River anticline outcrops, cross-fold (perpendicular to the fold axis), strike-parallel (parallel to the fold axis), and cross-strike (oblique to the fold axis), their orientation varying across the fold with structural position. They concluded that local stresses were the main control on fracture orientation in the area, although fracture orientations seem to have been overprinted by the 541 regional fracture sets present in the Plains to the east of the fold belt. These authors did not 542 conduct a fold-test, nor did they provide timing estimates of bed-perpendicular fractures with 543 respect to the formation of the fold.

544 In this study, we identified four main bedding-perpendicular sets, two of which share the same orientation. Fractures are not parallel and orthogonal to the fold axis, but are slightly oblique (sub-parallel and sub-perpendicular). Cross-cutting relationships indicate at least some fractures are fold-related but some might predate folding. Fault kinematics of bedding-parallel faults, thrust and reverse faults, and slip along set 4 fractures are compatible with the expected kinematics of folding (Figure 6d). Set 4 fractures cut or abut against low-angle thrust faults, and low-angle faults do not displace the blocks cut by set 4 fractures, indicating that set 4 postdates 551 low-angle thrust faults (Figure $\mathbf{6 b}$ ). Propagation and linkage that led to the formation of set 4 552 fractures is thus inferred to have occurred during folding, and reactivation in shear along set 4 553 fractures is the youngest event. When bedding is rotated to horizontal, and fractures are rotated 554 accordingly (fold test), the fracture orientations cluster more tightly than the unrotated 555 (measured) fracture orientations, suggesting that sets 1-3 formed when bedding was flat, prior to 556 folding of the Red Deer River anticline, and were rotated during folding. However, it is conceivable that fracture orientation can be influenced by the layer anisotropy, with fractures 
forming perpendicular to bedding, regardless of bedding dip. Thus, bedding-perpendicular fractures may have formed either prior to or during folding.

The Canadian Rocky Mountains have undergone a protracted history of SW-NE contraction (Bally et al., 1966; Eisbacher et al., 1974; Price, 1994), which continues to the 562 present day. Opening-mode fractures analyzed in this study thus record a relatively small amount 563 of extension ( $1-10 \%)$ superimposed on overall regional contraction that resulted in $\mathrm{km}$-scale 564 reverse faults. Because of this prolonged stress field, the main orientation of mode I fractures in 565 the Canadian Rocky Mountains and the West Central Alberta Basin is predicted to be SW-NE, 566 which is confirmed by fractures in outcrop and core, and borehole break-out data (Bell and 567 Gouh, 1979; Dechesne and Veilleux, 2000). In our study area, after unfolding the strata, fracture 568 set 1 , the oldest set, and set 4 , the youngest set, are oriented subparallel to the present-day 569 maximum horizontal in-situ stress trend of 45-60 (Figure 5b). In some wells east of the fold570 and-thrust belt an additional fracture set striking $330^{\circ}$ has been observed (Dechesne and 571 Veilleux, 2000). Fracture set 3 in our study area strikes $\sim 300^{\circ}$ differing by $\sim 30^{\circ}$ from this 572 regional set. No regional set of fractures has been reported in the orientation of set $2\left(\sim 0-30^{\circ}\right)$.

573 The homogeneity we observe in macro- and microfracture intensity across the Red Deer 574 River anticline, especially for fractures $>0.1 \mathrm{~mm}$ in aperture, is compatible with either a pre- or 575 synfolding origin of fracture sets 1-3 (Figure 8). We infer that bioturbation is more important 576 than layer thickness on governing fracture abundance in the Cardium Formation. Bioturbation 577 generally marks slightly deeper water sandstone deposits that have higher proportions of 578 compliant and fine-grained materials. These slight compositional changes along with the textural 579 homogenization accompanying bioturbation result in different mechanical properties from clean 
580 and bioturbated sandstones and a widely recognized propensity for such sandstones to have 581 lower fractures abundance (e.g., Nelson, 1985; Laubach et al., 2009).

582 Pre-folding fractures can become reactivated during folding leading to re-opening, 583 shearing, and linkage of existing fractures, and formation of new macro- and microfractures 584 (Dunne 1986; Laubach, 1988; Davatzes and Aydin, 2003; Bergbauer and Pollard, 2004). Such a reactivation model was proposed for similar folds and rock types by Inigo et al. (2012). The progressive addition of fractures that would result from this model is compatible for long-lived partly open large fractures (e.g., Laubach and Ward, 2006). If such fractures were cemented concurrently or synkinematically with fracture opening they might record past fold-related strain, even if they are in parts of the fold not currently in an area of high curvature (for example, former hinges that have been unfolded). Fractures in the Cardium Formation are generally cemented with synkinematic quartz cement (Figure 7), which would prevent closure of fractures when stress and strain conditions change in the fold during progressive evolution of the thrust sequence.

Two kinematic models have previously been proposed to predict the occurrence of opening-mode fractures in folds: fixed-hinge (De Sitter, 1956) and active-hinge (Suppe, 1985) models. Fixed-hinge folding implies no material migration across axial surfaces while limbs rotate about a fixed axial surface (De Sitter, 1956; McConnell, 1994; Salvini and Storti, 2004; Gosh and Saha, 2005; Mercier, 2007), while active-hinge folding implies material migration across axial surfaces relative to a stable position of a ramp (Suppe et a., 1992). Both mechanisms can produce folds having a similar appearance, but the deformation patterns would be different (Fisher et al., 1992; Salvini and Storti, 2001). For a fold where the hinge is stationary, strain is contractional in the inner arc, and extensional in the outer arc of the folded layer. Therefore, the 
highest extensional strain is expected to be accommodated by opening-mode fractures in the hinge of a fold. Thus, fixed-hinge models can be used to predict spatial distribution of deformation as a function of layer curvature (Murray, 1968; Decker et al., 1989; Schultz-Ela and Yeh, 1992; Lemiszki et al., 1994; Lisle, 1994; Hennings et al., 2000; Fisher and Wilkerson, 2000). In contrast, active-hinge folding results in hinge migration where the distribution of high deformation intensity and associated strain tracks the hinge migration path (Suppe, 1983; Fischer et al., 1992; Salvini and Storti, 2004).

Strain calculations using Move software for the Red Deer River anticline predict that fault-related fold development results in a complex strain path throughout deformation consistent with active-hinge folding (Figures 12 and 13), and with extensional strain localized primarily in the fold limbs. Strain calculation provides information about the timing of strain that could lead to fracture opening relative to the thrust evolution. While incremental strain provides a proxy for predicting fracture opening at specific stages of fold and thrust evolution, the cumulative strain can be considered a proxy for strain accommodated by fractures cemented by mineral cement concurrently or synkinematically with fracture opening, thus preserving fracture aperture.

Fracture strain calculated from scanlines and from kinematic models are comparable in magnitude. Incremental $e_{x x}$ values modeled with Move are as high as 0.1 around the Red Deer River anticline (Figure 12) but in most cases strain values are within the same order of magnitude as those derived from microfractures in the field. Strain magnitudes derived from microfracture and macrofracture data from field samples are between 0.001 and 0.009 using method 1, and 0.005 and 0.03 using method 2 when $\mathrm{D}_{\max }$ is $0.1 \mathrm{~mm}$. In contrast, strain calculated based on fractures up to $1 \mathrm{~mm}$ in aperture using method 2 is generally one order of magnitude greater, between 0.008 and 0.05 . This difference highlights the scale-dependency of strain 
measurements (Marrett, 1996). We recognize that the integrated strain calculated based on a $\mathrm{D}_{\max }$

$627=1 \mathrm{~mm}$ probably overestimates true fracture strain as indicated by an overall scarcity of

628 medium-sized fractures in these samples. In comparison to the strain results derived from Move,

629 the fracture strain observed in the planar-laminated upper portion of the Kakwa Member shows

630 little variation across the three domains (Figure 8), with Domain II, the upper section of the

631 forelimb, showing somewhat lower strain than the lower forelimb (Domain III) and the backlimb

632 (Domain I). Although the number of strain measurements in the upper portion of the Kakwa

633 Member is not evenly distributed across the three domains (with only one measurement in

634 Domain III), we find that the strain distribution is consistent with the cumulative strain

635 calculations in Move (Figure 9). Similar extension magnitudes, on the order of $\sim 1-10 \%$, have

636 been reported for many geological examples (e.g., Narahara and Wiltschko, 1986; Jamison,

637 1997; Gross and Engelder, 1995; Inigo et al., 2012), irrespective of the tectonic setting. The

638 similarity between fracture strain calculated using methods 1 and 2 for equivalent scales

639 highlights the robustness of the method.

640 Kinematic models indicate that the largest incremental extension would occur in the backlimb of 641 the Red Deer River anticline early in the development of the Burnt Timber thrust (Figure 12, stage d) 642 when the forelimb undergoes a shortening phase. If fracturing were associated with folding, most 643 opening-mode fractures would thus form during this stage. However, cumulative strains (Figure 13) in 644 both limbs of the anticline are roughly similar from stage d onward, with somewhat higher extension in 645 the backlimb and lower extension in the forelimb close to the crest of the fold. These models thus predict 646 that strain recorded by fold related, bed-perpendicular opening-mode fractures would be similar in both 647 limbs of the fold. Cumulative strain calculated by Move is thus compatible with our strain measurements 648 using scanlines and indicates opening and cementation of fractures during early folding. Such a rather 649 uniform strain across the fold could also suggest fracture formation prior to folding and subsequent 
650 reactivation. In Alberta, we found evidence for faulting and reactivation in shear of probable 651 earlier-formed opening-mode fractures. Reactivation of fractures is predicted by geomechanical 652 models and extensive evidence for reactivation is found in outcrop (e.g., Guiton et al., 2003; 653 Smart et al., 2009). In folds of about the same age in Wyoming, Bergbauer and Pollard (2004), 654 found evidence that the orientation of pre-existing fractures controlled the internal structures and 655 the orientation of fractures that form later in the deformation history. Tall, thoroughgoing 656 fractures may be susceptible to reactivation (Becker and Gross, 1996). The linkage geometry we 657 observed of through-going set 4 fractures together with evidence of shear offset suggests that 658 they formed by reactivation and linkage of earlier set 1 , bedding-confined fractures. We 659

speculate that set 1 fractures contributed to the mechanical weakness that may have influenced subsequent fracturing during multiple phases of brittle deformation.

\section{CONCLUSIONS}

Opening-mode fractures are prominent in surface exposures of the Cardium Formation within the Red Deer River anticline. Three main opening-mode fracture sets were identified, and fracture spacing and aperture data were collected along both macro- and microscanlines. These data indicate that variations in fracture intensity between the fracture sets are small among the backlimb (Domain I), upper forelimb (Domain II), and lower forelimb (Domain III) across the fold, yet the intensity is slightly lower in the upper forelimb versus the backlimb and lower forelimb of the anticline, which are both higher (and equal) in intensity.

The large-scale fold geometry of the Red Deer River anticline can be explained by kinematic restoration of regional-scale cross-sections and forward modeling. These kinematic models suggest that this anticline developed by active-hinge migration resulting from slip along the underlying Burnt Timber thrust. A comparison of measured fracture strain with the kinematic 
673 model predictions suggests that the observed fracture strain distribution across the three

674 structural domains is consistent with fracture formation during early development of the Red

675 Deer River anticline. However, a pre-folding origin of the fractures cannot be excluded because

676 the differences in measured fracture strain across the three structural domains of the fold are

small, and layer-to-layer variation in folding strain within each domain are large.

Formation of fractures prior to, or at the onset of, folding is consistent with systematic 679 angular relations between the three bed-bounded, high-angle-to-bedding sets of opening-mode 680 fractures, which suggests that the fractures were progressively rotated as bedding planes were 681 folded. Commonly observed through-going fractures formed by propagation and linkage are 682 associated with wing cracks and show both strike-slip and dip-slip senses of shearing, which are 683 kinematically compatible with folding. This suggests that through-going fractures were 684 reactivated in shear during the later stages of fold development.

685 Because a different strain distribution is predicted for different parts of the fold at 686 different times during deformation, the numerical simulations performed in this study 687 demonstrate that fold evolution within deforming fold-and-thrust-belts can result in complex 688 distributions of bedding-parallel extension, and thus in the formation of opening-mode fractures, 689 in both space and time.

\section{ACKNOWLEDGEMENTS}

692 Geosciences and Biosciences Division, Office of Basic Energy Sciences, Office of Science, U.S. 693 Department of Energy and by the Fracture Research and Application Consortium at The 694 University of Texas at Austin. We are grateful to R. Marrett and S. E. Laubach for discussions. 
CO thanks Turkish Petroleum Corporation (TPAO) for student scholarship support. The authors would like to thank Peter Fermor, Dennis Meloche, and Rob Day (Devon) for assistance in the field and fruitful discussions, and Nico Hardebol, Peter Fermor and two anonymous reviewers for helpful suggestions for improvement of the manuscript. Published with the permission of the Director, Bureau of Economic Geology.

\section{REFERENCES}

Bally, A. W., Gordy, P., and Stewart, G. A., 1966, Structure, seismic data, and orogenic evolution of southern Canadian Rocky Mountains. Bulletin of Canadian Petroleum Geology14, 337-381.

Barton, C. C., 1983, Systematic jointing in the Cardium sandstone along the Bow River, Alberta, Canada: Phd dissertation, Yale University, 301 p.

Beaumont, C., 1981, Foreland basins. Royal Astronomical Society Geophysical Journal International 65, 291-329.

Becker, A., and Gross, M. R., 1996, Mechanism for joint saturation in mechanically layered rocks: an example from southern Israel. Tectonophysics 257, 223-237.

Beekman, F., Badsi, M. and van Wees, J.-D., 2000, Faulting, fracturing and in situ stress prediction in the Ahnet Basin, Algeria-A finite element approach. Tectonophysics 320, 311-329.

Bell, J. S. and Gough, D. I., 1979, Northeast-southwest compressive stress in Alberta: Evidence from oil wells. Earth and Planetary Science Letters 45, 475-482.

Bellahsen, N., Fiore, P. and Pollard, D.D., 2006, The role of fractures in the structural interpretation of Sheep Mountain Anticline, Wyoming. Journal of Structural Geology 28, $850-867$.

Bergbauer, S., and Pollard, D. D., 2004, A new conceptual fold-fracture model including prefolding joints, based on the Emigrant Gap anticline, Wyoming. Geological Society of America Bulletin 116, 294-307.

Boettcher, D., Thomas, M.. Hrudey, M., Lewis, D., O'Brien, C., Oz, B., Repol, D., and Yuan, R., 2010, The Western Canada Foreland Basin: a basin-centred gas system: Petroleum 
Geology: From Mature Basins to New Frontiers - Proceedings of the 7th Petroleum Geology Conference., 1099-1123.

Casini, G., and Gillespie, P.A. , 2011, Sub-seismic fractures in foreland fold and thrust belts: Insight from the Lurestan Province, Zagros Mountains, Iran. Petroleum Geoscience 17, 263-282.

Cooper, M., 1992, The analysis of fracture systems in subsurface thrust structures from the foothills of the Canadian Rockies. Thrust tectonics, London, Chapman and Hall, 391-405.

Currie, J. B., and Nwachukwu, S. O., 1974, Evidence on incipient fracture porosity in reservoir rocks at depeth. Bulletin of Canadian Petroleum Geology 22, 42-58.

Currie, J. B., and Reik, G. A., 1976, A method of distinguishing regional directions of jointing and of identifying joint sets associated with individual geologic structures. Canadian Journal of Earth Sciences 14, 1211-1228.

Davatzes, N.C., and Aydin, A., 2003. The formation of conjugate normal fault systems in folded sandstone by sequential jointing and shearing, Waterpocket monocline, Utah. Journal of Geophysical Research: Solid Earth 108, 2478.

Decker, A.D., Close, J. C., and McBane, R. A., 1989, The use of remote sensing, curvature analysis, and coal petrology as indicators of higher coal reservoir permeability. Proceedings of the International Coalbed Methane Symposium 16, 325-340.

Dechesne and Veilleux, 2000, Fractured Cretaceous and Triassic strata of the Central Alberta Foothills, GeoCanada 2000, Field Trip Guidebook n. 22.

De Sitter, L. U., 1964, Structural geology, McGraw-Hill Book Co., New York, 551 p.

Dunne, W. M., 1986, Mesostructural development in detached folds: an example from West Virginia. Journal of Geology 94, 473-488.

Eisbacher, G., Carrigy, M. A., and Campbell, R. B., 1974, Paleodrainage pattern and lateorogenic basins of the Canadian Cordillera: Tectonics and Sedimentation, The Society of Economic Paleontologists and Mineralogists (SEPM) 22,143-166.

Engelder, T., 1985, Loading paths to joint propagation during a tectonic cycle: An example from the Appalachian Plateau, U.S.A. Journal of Structural Geology 7, 459-476.

Engelder, T. and Plumb, R., 1984, Changes in in situ ultrasonic properties of rock on strain relaxation, International Journal of Rock and Mining Sciences 21, 75-82.

English, J., 2012, Thermomechanical origin of regional fracture systems. AAPG Bulletin 96, 1597-1625.

Erslev, E.A., 1991, Trishear fault-propagation folding. Geology 19, 617-620.

Fall, A., Eichhubl, P., Cumella, S. P., Bodnar, R. J., Laubach, S. E., and Becker, S. P., 2012, Testing the basin-centered gas accumulation model using fluid-inclusion observations: Southern Piceance Basin, Colorado. AAPG Bulletin 96, 2297-2318.

Fall, A., Eichhubl, P., Bodnar, R. J., Laubach, S. E., and Davis, J. S., 2015, Natural hydraulic fracturing of tight-gas sandstone reservoirs, Piceance Basin, Colorado. Geological Society of America Bulletin 127, 61-75. 
Fermor, P., 1999, Aspects of the three-dimensional structure of the Alberta Foothills and Front Ranges. Geological Society of America Bulletin 111, 317-346.

Fischer, M., Woodward, N., and Mitchell, M., 1992, The kinematics of break-thrust folds. Journal of Structural Geology 14, 451-460.

Fischer, M. P., Wilkerson, M.S, 2000, Predicting the orientation of joints from fold shape: results of pseudo-three-dimensional modeling and curvature analysis. Geology 28, 15-18.

Florez-Niño, J.-M., Aydin, A., Mavko, G., Antonellini, M. and Ayaviri, A., 2005, Fault and fracture systems in a fold and thrust belt: An example from Bolivia. AAPG Bulletin, 89, 471-493.

Ford, M. E., Williams, A., Artoni, A., Verges, J., and Hardy, S., 1997, Progressive evolution of a fault-related fold pair from growth strata geometries, Sant Llorenc de Morunys, SE Pyrenees. Journal of Structural Geology 19, 413-441.

Friedman, M., 1969. Structural analysis of fractures in cores from the Saticoy Field, Ventura Co., California. AAPG Bulletin, 53, 367-389.

Ghosh, G. and Saha, D., 2005, Kinematics of large scale asymmetric folds and associated smaller scale brittle - Ductile structures in the proterozoic somnur formation, pranhita - Godavari Valley, South India. Journal of Earth System Science 114, 125-142.

Ghosh, K. and Mitra, S., 2009, Structural controls of fracture orientations, intensity, and connectivity, Teton anticline, Sawtooth Range, Montana. AAPG Bulletin 93, 995-1014.

Gomez, L. A., and Laubach, S. E., 2006, Rapid digital quantification of microfracture populations. Journal of Structural Geology 28, 408-420.

Gordy, P.L., and Frey, F. R., 1975, Structural cross sections through the Foothills west of Calgary, in Evers, H. J., and Thorpe, J. E., eds., Geology of the Foothills between Savanna Creek and Panther River, southwestern Alberta, Canada, Guidebook: Calgary, Alberta, Canadian Society of Petroleum Geologists and Canadian Society of Exploration Geophysicists, 37-64.

Graham, B., Antonellini, M., and Aydin, A., 2003, Formation and growth of normal faults in carbonates within a compressive environment. Geology 31, 11-14.

Griffiths, P., Jones, S., Slater, N., Schaefer, F., Osfield, R., and Reiser, H., 2002, A new technique for 3-D flexural-slip restoration. Journal of Structural Geology 24, 773-782.

Gross, M. R., and Engelder, T., 1995, Strain accommodated by brittle failure in adjacent units of the Monterey Formation, U.S.A.: scale effects and evidence for uniform displacement boundary conditions. Journal of Structural Geology 17, 1303-1318.

Guiton, M. L. E., W. Sassi, Y. M. Leroy, and B. D. M. Gauthier, 2003b, Mechanical constraints on the chronology of fracture activation in folded Devonian sandstone of the western Moroccan Anti-Atlas, Journal of Structural Geology, 25(8), 1317-1330, doi:10.1016/S0191-8141(02)00155-4.

Hanks, C.L., Wallace, W.K., Atkinson, P.K., Brinton, J., Bui, T., Jensen, J.and Lorenz, J., 2004, Character, relative age and implications of fractures and other mesoscopic structures associated with detachment folds: an example from the Lisburne Group of the 
Hancock, P., 1985, Brittle microtectonics: principles and practice. Journal of structural geology 7, 437-457.

Hardebol, N. J., Callot, J. P., Bertotti, G., and Faure, J. L., 2009, Burial and temperature evolution in thrust belt systems: Sedimentary and thrust sheet loading in the SE Canadian Cordillera. Tectonics 28, TC3003, doi:10.1029/2008TC002335.

Hennings, P. H., Olson, J.E. and Thompson, L.B., 2000, Combining outcrop data and threedimensional models to characterize fractured reservoirs: An example from Wyoming. AAPG Bulletin 84, 830-849.

Hitchon, B., 1985, Geothermal gradients, hydrodynamics, and hydrocarbon occurrences, Alberta, Canada: AAPG Bulletin, v. 68, p. 713-743.

Hooker, J. N., Laubach, S.E., and Marrett, R., 2015, A universal power-law scaling exponent for fracture apertures in sandstones. Geological Society of America Bulletin 126, 13401362.

Hooker, J.N., Laubach, S.E., and Marrett, R., 2013, Fracture-aperture size-frequency, spatial distribution, and growth processes in strata-bounded and non-strata-bounded fractures, Cambrian Mesón Group, NW Argentina. Journal of Structural Geology 54, 54-71. doi.org/10.1016/j.jsg.2013.06.011.

Iñigo, J. F., Laubach, S. E., and Hooker, J. N., 2012, Fracture abundance and patterns in the Subandean fold and thrust belt, Devonian Huamampampa Formation petroleum reservoirs and outcrops, Argentina and Bolivia. Marine \& Petroleum Geology 35, 201218. doi:10.1016/j.marpetgeo.2012.01.010.

Jäger, P., S. Schmalholz, D. Schmid, and E. Kuhl, 2008, Brittle fracture during folding of rocks: A finite element study. Philosophical Magazine 88, 3245-3263.

Jamison, W. R., 1997, Quantitative evaluation of fractures on Monkshood anticline, a detachment fold in the foothills of western Canada. AAPG Bulletin 81, 1110-1132

Johnson, K.M. and Johnson, A.M., 2002, Mechanical models of trishear-like folds. Journal of Structural Geology 24, 277-287.

Krause, F., K., Deutsch, K.B., Joiner, S.D., Barclay, J.E., Hall, R.L. and Hills, L.V., 1994, Chapter 23, Cretaceous cardium formation of the Western Canada sedimentary basin In: Atlas of the Western Canada Sedimentary Basin. Geological Atlas of the Western Canada Sedimentary Basin. GD Mossop and I. Shetson (eds.). Alberta Research Council and Canadian Society of Petroleum Geologists, 485-511.

Kubli, T. E. and Langenberg,C. W., 2002, Cross section Red Deer River Area, in EUB/AGS Earth Sciences Report 2002-05 Regional Evaluation of the Colabed Methane Potential of the Foothills/Mountains of Alberta (Second Edition), C. W., Lnagenberg, A. Beaton and H. Berhane, Alberta Geological Survey.

Laubach, S. E., 1988, Fractures generated during folding of the Palmerton Sandstone, eastern Pensylvania. Journal of Geology 96, 495-503. 
Laubach, S. E. and Ward, M. W., 2006, Diagenesis in porosity evolution of opening-mode fractures, Middle Triassic to Lower Jurassic La Boca Formation, NE Mexico. Tectonophysics 419, 75-97.

Laubach, S. E., Olson, J. E, and Gross, M. R., 2009, Mechanical and fracture stratigraphy. AAPG Bulletin 93, 1413-1426.

Leckie, D. A. and Smith., D.G., 1992, Regional setting, evolution and depositional cycles of the Western Canadian foreland basin. In: Foreland Basins and Fold Belts. AAPG Memoir 55, 9-46

Lemiszki, P. J., Landes, J. D., and Hatcher, R. D., 1994, Controls on hinge-parallel extension fracturing in single-layer tangential-longitudinal strain folds. Journal of Geophysical Research: Solid Earth 99, 22027-22041.

Lisle, R. J., 1994, Detection of zones of abnormal strains in structures using Gaussian curvature analysis. AAPG Bulletin 78, 1811-1819.

Maerten, F., and Maerten, L., 2006, Chronologic modeling of faulted and fractured reservoirs using a geomechanically based restoration: technique and industry applications. AAPG Bulletin 90, 1201-1226.

Marrett, R., 1996, Aggregate properties of fracture populations. Journal of Structural Geology $18,169-178$.

Marrett, R., and Laubach, S. E., 2001, Fracturing during burial diagenesis, in Marrett, R., ed., Genesis and controls of reservoir-scale carbonate deformation, Monterrey salient, Mexico: The University of Texas at Austin, Bureau of Economic Geology, Guidebook 28, 109-120.

Marrett, R., Ortega, O. J., and Kelsey, C. M., 1999, Extent of power-law scaling for natural fractures in rock. Geology 27, 799-802.

McConnell, D. A., 1994, Fixed-hinge, basement-involved fault-propagation folds, Wyoming. Geological Society of America Bulletin 106, 1583-1593.

Meglis, I. L., Engelder, T. and Graham, E. K., 1991, The effect of stress-relief on ambient microcrack prosity in core samples from the Kent Cliffs (New York) and Moodus (Connecticut) scientific research boreholes. Tectonophysics 186, 163-173.

Mercier, E., Rafi, S., and Ahmadi, R., 2007, Folds kinematics in "Fold-and-Thrust Belts" the "Hinge Migration" question, a review, Thrust Belts and Foreland Basins, From Fold Kinematics to Hydrocarbon Systems, Chapter 7. Frontiers in Earth Sciences., Springer Berlin, Heidelberg, 135-147.

Milliken, K. L. and Laubach, S. E, 2000, Brittle deformation in sandstone diagenesis as revealed by cathodoluminescence imaging with application to characterization of fractured reservoirs. Cathodoluminescence in geosciences, Chapter 9, Heidelburg, Springer-Verlag, 225-244.

Monger, J.W.H., 1989, Chapter 2, Overview of Cordilleran Geology. In: Western Canada Sedimentary Basin: A Case History. B.D. Ricketts (ed.). Calgary, Canadian Society of Petroleum Geologists, 9-32.

Muecke, G. and Charlesworth, H., 1966, Jointing in folded Cardium sandstones along the Bow River, Alberta. Canadian Journal of Earth Sciences 3, 579-596. 
Murray Jr, G. H., 1968, Quantitative Fracture Study--Sanish Pool, Mckenzie County, North Dakota. AAPG Bulletin 52, 57-65.

Narahara, D. K., and Wiltschko, D.V., 1986, Deformation in the hinge region of a chevron fold, Valley and Ridge Province, central Pennsylvania. Journal of Structural Geology 8, 157168.

Narr, W. and Currie, J. B., 1982, Origin of fracture porosity--example from Altamont field, Utah. AAPG Bulletin 66, 1231-1247.

Nelson, R. A., 1985, Geological analysis of naturally fractured reservoirs. Contributions in Petroleum Geology and Engineering, Gulf Publishing Co., Houston, TX, 320 p.

Newson, A. C., 2001, The future of natural gas exploration in the Foothills of the Western Canadian Rocky Mountains. The Leading Edge 20, 74-79.

Nickelsen, R. P., 1979, Sequence of structural stages of the Alleghany Orogeny a the Bear Valley strip mine, Shamokin, Pennsylvania. American Journal of Science 279, 225-271.

Novoa, E., Suppe, J., and Shaw, J. H., 2000, Inclined-shear restoration of growth folds. AAPG Bulletin 84, 787-804.

Ollerenshaw, N. C., 1966, Geology, Burnt Timber Creek, West of Fifth Meridian, Alberta, Geological Survey of Canada, Preliminary Map 11-1965 (1:63 360).

Ortega, O. J., Marrett, R. A., and Laubach, S. E., 2006, A scale-independent approach to fracture intensity and average spacing measurement. AAPG Bulletin 90, 193-208.

Pana, D. I. and Elgr, R., 2013, Geology of the Alberta Rocky Mountains and Foothills. Energy Resources Conservation Board Map 560 (1:500000).

Plint, A. G., Walker, R. G., and Duke, W. L., 1988, An outcrop to subsurface correlation of the Cardium Formation in Alberta. Canadian Society of Petroleum Geologists 15, 167- 184.

Poblet, J. and McClay, K., 1996, Geometry and kinematics of single-layer detachment folds. AAPG Bulletin 80, 1085-1109.

Poblet, J., McClay, K., Sotrti, F., and Muñoz, J. A., 1997, Geometries of syntectonic sediments associated with single layer detachment folds. Journal of Structural Geology 19, 369-381.

Price, N. J., 1966, Fault and joint development in brittle and semi-brittle rock, v. 1, Pergamon Press Oxford.

Price, R. A., 1973, Large-scale gravitational flow of supracrustal rocks, southern Canadian Rockies: In: Gravity and Tectonics. K.A. De Jong and R. Scholten (eds.) New York, Wiley and Sons, 491-502.

Price, R., 1981, The Cordilleran foreland thrust and fold belt in the southern Canadian Rocky Mountains: Thrust and Nappe Tectonics, ed. MP Coward, KR McClay. Geological Society of London Special Publication 9, 427-28.

Price, N. J. and Cosgrove., J.W., 1990, Analysis of geological structures: Cambridge, Cambridge University Press.

Price, R., 1994, Cordilleran tectonics and the evolution of the Western Canada Sedimentary Basin: Geological Atlas of the Western Canada Sedimentary Basin G.D. Mossop and I. 
Shetsen (compilers) Canadian Society of Petroleum Geologists and Alberta Research Council 4, 13-24.

Ramsay, J.G., 1980. The crack-seal mechanism of rock deformation. Nature 284, 135-139.

Reif, D., Decker, K., Grasemann, B., and Peresson, H. , 2012, Fracture patterns in the Zagros fold-and-thrust belt, Kurdistan Region of Iraq. Tectonophysics 576-577, 46-62.

Rottenfusser, B., Langenberg, W., Mandryk, G., Richardson, R., Fildes, B., Olic, J., Stewart, S., Eccles, R., Evans, C., Spelrem, M., Sprecher, B., Brulotte, M., Gentzis, T., Wynne, D. and Yuan, L.P., 1991, Regional evaluation of the coal bed methane potential in the plains and foothills of Alberta,stratigraphy and rank study. Alberta Research Council Special Report SPE-7, 126 p.

Rouby, D., Xiao, H., and Suppe, J., 2000, 3-D restoration of complexly folded and faulted surfaces using multiple unfolding mechanisms. AAPG Bulletin 84, 805-829.

Salvini, F. and Storti, F., 2001, The distribution of deformation in parallel fault-related folds with migrating axial surfaces: comparison between fault-propagation and fault-bend folding. Journal of Structural Geology 23, 25-32.

Salvini, F. and Storti, F., 2002, Three-diemnsional architecture of growth strata associated to fault-bend, fault-propagation, and décollement anticlines in non-erosional environments. Sediemntary Geology 146, 57-73.

Salvini, F. and F. Storti, 2004, Active-hinge-folding-related Deformation and its Role in Hydrocarbon Exploration and DevelopmentInsights from HCA Modeling: Thrust Tectonics and Petroleum Systems. AAPG Memoir 82, 453-472.

Schultz-Ela, D. D. and Yeh, J. S., 1992, Predicting fracture permeability from bed curvature, Rock mechanics. Proceedings, 33rd U.S. symposium, Rotterdam, Balkema, 579-589.

Shackleton, J. R., Cooke, M. L., Verges, J., and Simo, T., 2011, Temporal constraints on fracturing associated with fault-related folding at Sant Corneli anticline, Spanish Pyrenees. Journal of Structural Geology 33, 5-19.

Smart, K. J., D. a. Ferrill, and A. P. Morris, 2009, Impact of interlayer slip on fracture prediction from geomechanical models of fault-related folds, AAPG Bulletin 93(11), 1447-1458, doi:10.1306/05110909034.

Smart, K.J., Ferrill, D.A., Morris, A.P., and McGinnis, R.N., 2012, Geomechanical modeling of stress and strain evolution during contractional fault-related folding. Tectonophysics 576-577, 171-196.

Stearns, D. W., 1968, Certain aspects of fracture in naturally deformed rocks. N.S.F. advanced science seminar in rock mechanics, 97-118.

Stearns, D.W. and Friedman, M., 1972, Reservoirs in fractured rocks. AAPG Memoir 16, 82100.

Stockmal, G.S., Cant, D.J., and Bell, J.S., 1992, Relationship of the Stratigraphy of the Western Canada Foreland Basin to Cordilleran Tectonics: Insights from Geodynamic Models. In: Leckie, D.A., McQueen, R.W. (Eds.), Foreland Basins and Fold Belts. AAPG Memoir $55,107-124$. 
Stott, D. F., 1963, The Cretaceous Alberta Group and equivalent rocks, Rocky Mountain Foothills, Alberta. Geological Survey of Canada, Memoir 317, 306 p.

Solano, N., Zambrano, L., and Aguilera, R. 2011. Cumulative-Gas-Production Distribution on the Nikanassin Tight Gas Formation, Alberta and British Columbia, Canada. SPE Reservoir Evaluation and Engineering 14, 357-376.

Suppe, J., 1983, Geometry and kinematics of fault-bend folding. American Journal of science $283,684-721$.

Suppe, J., and Medwedeff, D.A., 1990, Geometry and kinematics of fault-propagation folding. Ecologae Helvetiae 83, 409-454.

Suppe, J., Chou, G. T., and Hook, S. C., 1992, Rates of folding and faulting determined from growth strata. In Thurst Tectonics, ed. K. McClay, Chapman and Hall, London, 105-122.

Taerum, R. L., 2011, Effect of mechanical stratigraphy on structural style variations in the central Alberta fold and thrust belt: PhD Dissertation, University of Calgary, 228 p.

Tavani, S., Storti, F., Fernández, O., Muñoz, J.A., and Salvini, F., 2006, 3D deformation pattern analysis and evolution of the Añisclo anticline, southern Pyrenees. Journal of Structural Geology 28, 695-712.

Tavani, S., Storti, F., Salvini, F., and Toscano, C, 2008, Stratigraphic versus structural control on the deformation pattern associated with the evolution of the Mt. Catria anticline, Italy. Journal of Structural Geology 30, 664-681.

Tavani, S., Storti, F., Lacombe, O., Corradetti, A., Muñoz, J., and Mazzoli, S., 2014, Fracturing stages in foreland fold and thrust belts. European Geological Union General Assembly Conference Abstracts, 3030.

Thibert, B., Gratier, J. P., and Morvan, J. M., 2005, A direct emthod for modleing and unfolding developable surfaces and its application to the ventura basin, California. Journal of Structural Geology 27, 303-316.

Van, R. C. and Pedersen, P. K., 2015, Factors influencing production rates in the Raven River Member of the Cardium Formation in Garrington, Alberta. GeoConvention 2015, Geoscience New Horizons.

van der Plujim, B. A., Vrolijk, P. J., Pevear, D. R., Hall, C. M., and Solum, J., 2006, Fault dating in the Canadian Rocky Mountains: Evidence for late Cretaceous and early Eocene orogenic pulses. Geology 34(10), 837-840; doi: 10.1130/G22610.1.

Verges, J., Burbank, D. W., and Meigs, A., 1996, Unfodling: an inverse approach to fold kinematics. Geology 24, 175-178.

Walderhaug, O., 1994, Precipitation rates for quartz cement in sandstones determined by fluidinclusion microthermometry and temperature-history modeling. Journal of Sedimentary Research 64, 324-333.

Walderhaug, O., 1996, Kinetic modeling of quartz cementation and porosity loss in deeply buried sandstone reservoirs. AAPG Bulletin 80, 731-745.

Wall, J. H., 1967, Cretaceous foraminifera of the Rocky Mountain foothills, Alberta. Research Council of Alberta Bulletin 20, 119 p. 


\section{FIGURE CAPTIONS}

Figure 1: a) Tectonic subdivisions in the southern Canadian Cordillera, modified from Hardebol et al. (2009)..b) Geologic map of Ollerenshaw (1966) showing the location of cross-sections AA' and B-B'. WCSB: Western Canada Sedimentary Basin.

Figure 2: Stratigraphic column of the Alberta Foothills and Front Ranges (Gordy et al., 1975).

Figure 3: a) Panoramic view of the Red Deer River anticline (N 51³9'30.4'’W $115^{\circ} 17^{\prime} 12.2^{\prime \prime}$ ).

The anticline is subdivided into three structural Domains I-III. Sandstone members of the Cardium Formation in the study area are traced in white. Yellow dots (Sc-1 and Sc-2) indicate the location of the two macroscanlines measured in the field. Red dots and labels indicate the location of the hand samples collected for scaling analyses. b) Macroscanline Sc-2. c)

Macroscanline Sc-1. d) Close-up of Macroscanline Sc-2. Yellow line indicates the scanline. e) Close up of sample CO-14-2 showing vertical fractures. f) Location of sample RD-2 within Domain III on the south side of the Red Deer River. g) Location of samples CO-14-1, CO-14-2, and CO-14-3 stratigraphically above RD-2 within the same outcrop.

Figure 4: Schematic block diagram showing the orientation of the different fracture sets across the fold. Not to scale.

Figure 5a: Poles to fracture planes of the most prominent opening-mode fracture sets from different parts of the fold. Great circles indicate the orientation of bedding. Data shown in gray were measured in macroscanlines. Lower hemisphere projection. 
Figure 5b: Poles to fracture planes of the most prominent opening-mode fracture sets in different parts of the fold after bedding is rotated to horizontal. Data shown in gray were measured in macroscanlines. Lower hemisphere projection.

Figure 6: a) Through-going fractures (set 4) within the Kakwa Member in Domain II. Set 4 fractures probably formed by linkage and propagation of set 1 fractures (note the fracture clusters along which through-going fractures are concentrated). b) Inset showing wing cracks and offset layers that indicate dip-slip movement of $\sim 1 \mathrm{~cm}$. c) Set 4 fracture cutting across a low-angle thrust fault. d) Fault kinematics of representative low-angle thrust faults in Domain II. e) Rightlateral, strike-slip reactivation of set 4 fracture in Domain II. f) Representative low-angle thrust, and reactivation in shear and dip-slip, of steeply dipping set 4 fractures in Domain III south of the river. Fault kinematics are compatible with shearing related to folding. $\mathrm{TF}=$ thrust fault; RLSS = right-lateral strike-slip fault; LLSS = left-lateral strike-slip fault. Arrows indicate slip direction of the hanging wall.

Figure 7: a) SEM-CL image of set 3 fracture fill showing the euhedral nature of the quartz crystals and preserved porosity. Sample RD-2B-A. b) Set 3 fracture showing crack-seal texture along the fracture wall and euhedral cement fill away from the wall. Sample RD-2B-D. c) SEMCL image of set 1 fracture fill showing the euhedral nature of the quartz crystals and preserved porosity. Sample CO-14-2a-d. d) SEM-CL image of example cross-cutting and abutting fractures. Note the crack-seal texture of the narrow set 1 (vertical) and set 3 (horizontal) factures, whereas the wider set 1 fracture (upper left) is mostly infilled with euhedral quartz cement. Sample CO-14-2a-d. CS = crack-seal; $\mathrm{E}=$ euhedral quartz; $\mathrm{P}=$ porosity. 
Figure 8a: Cumulative frequency versus kinematic aperture plots of microfracture sets 1-3 in the three structural domains. Open symbols are for macrofractures measured in scanlines 1 and 2.

The red line has a slope of -0.8. Extrapolation of microfracture data using a constant slope of -0.8 gives a good prediction of macrofracture abundance. Dashed gray lines mark the intensity of 0.1 $\mathrm{mm}$ aperture fractures.

Figure 8b: Cumulative frequency versus kinematic aperture plots of microfractures showing the effect of lithology on fracture abundance.

Figure 9: Fracture strain plot according to structural position and lithology. Symbols outlined in black are for calculations using macroscanlines $>0.1 \mathrm{~mm}$ in aperture.

Figure 10: Balanced and simplified cross-sections A-A' (a) and B-B` (b) used for the construction of the 3D kinematic model. Circled numbers indicate fault numbers referred to in the text. Colors in the legend indicate the top of each formation. The stratigraphic column has been simplified. c) Original cross-section of Ollerenshaw (1966), which corresponds to the trace of cross-section B-B'. Stratigraphic sequence and colors as in Figure 1b.

Figure 11: Retrodeformed cross-section B-B'. The now-eroded strata around the hinge of the Red Deer River anticline and above the Burnt Timber thrust are shown in dashed lines.

Figure 12: Incremental evolution of the horizontal elongation component $e_{x x}$ (non-cumulative) for the Cardium Formation. Stratigraphic horizon colors are the same as in Figure 10. Color scale bars indicate magnitude of $\mathrm{e}_{\mathrm{xx}}$ in each case for the deforming top of the Cardium Formation. 
Figure 13: Evolution of the horizontal elongation component $\mathrm{e}_{\mathrm{xx}}$ (cumulative) for the Cardium

71068 Formation. Stratigraphic horizon colors are the same as in Figure 10. Color scale bars indicate

8

91069 magnitude of $\mathrm{e}_{\mathrm{xx}}$ in each case for the deforming top of the Cardium Formation. 


\section{Figure 1}
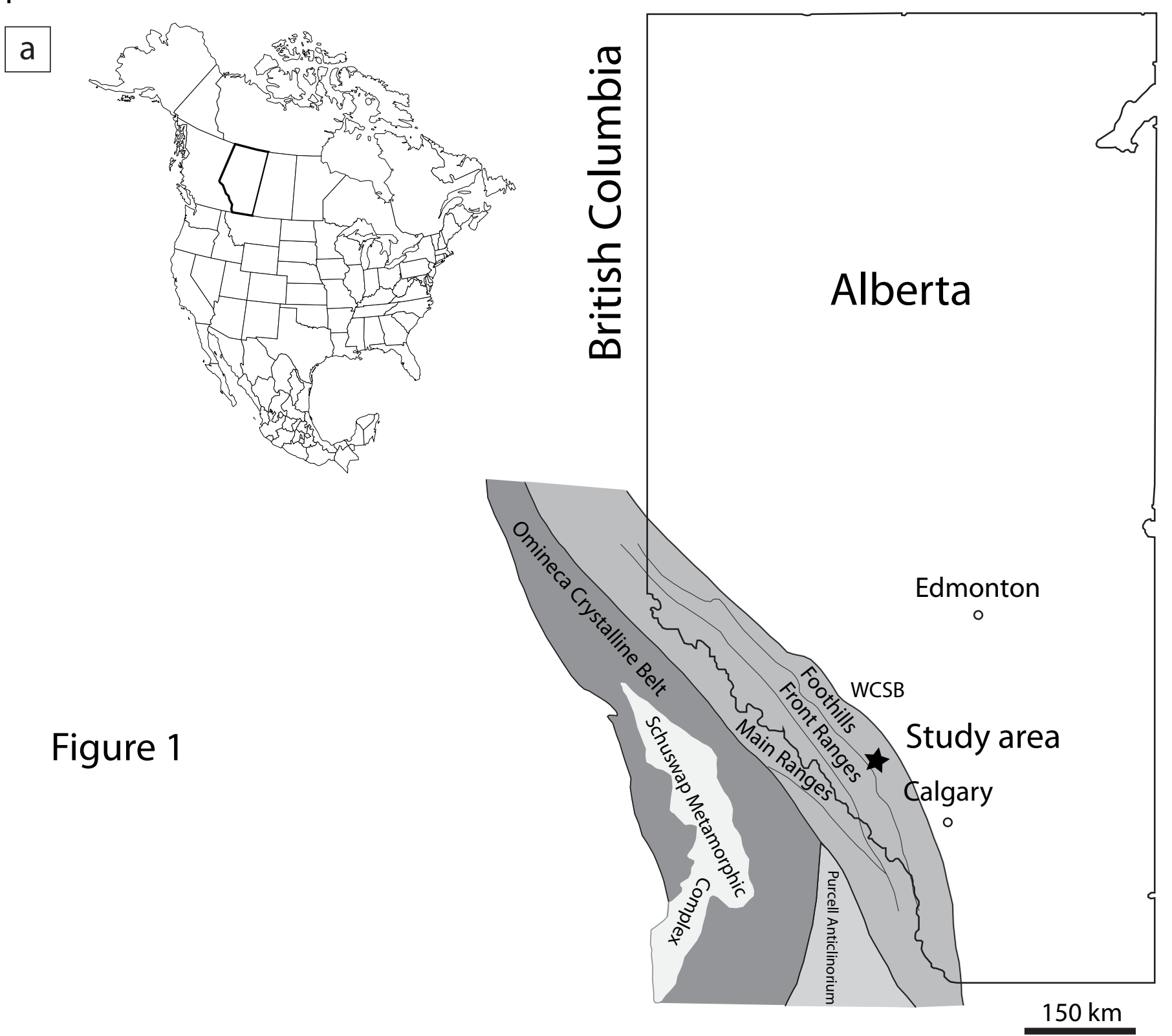

Figure 1

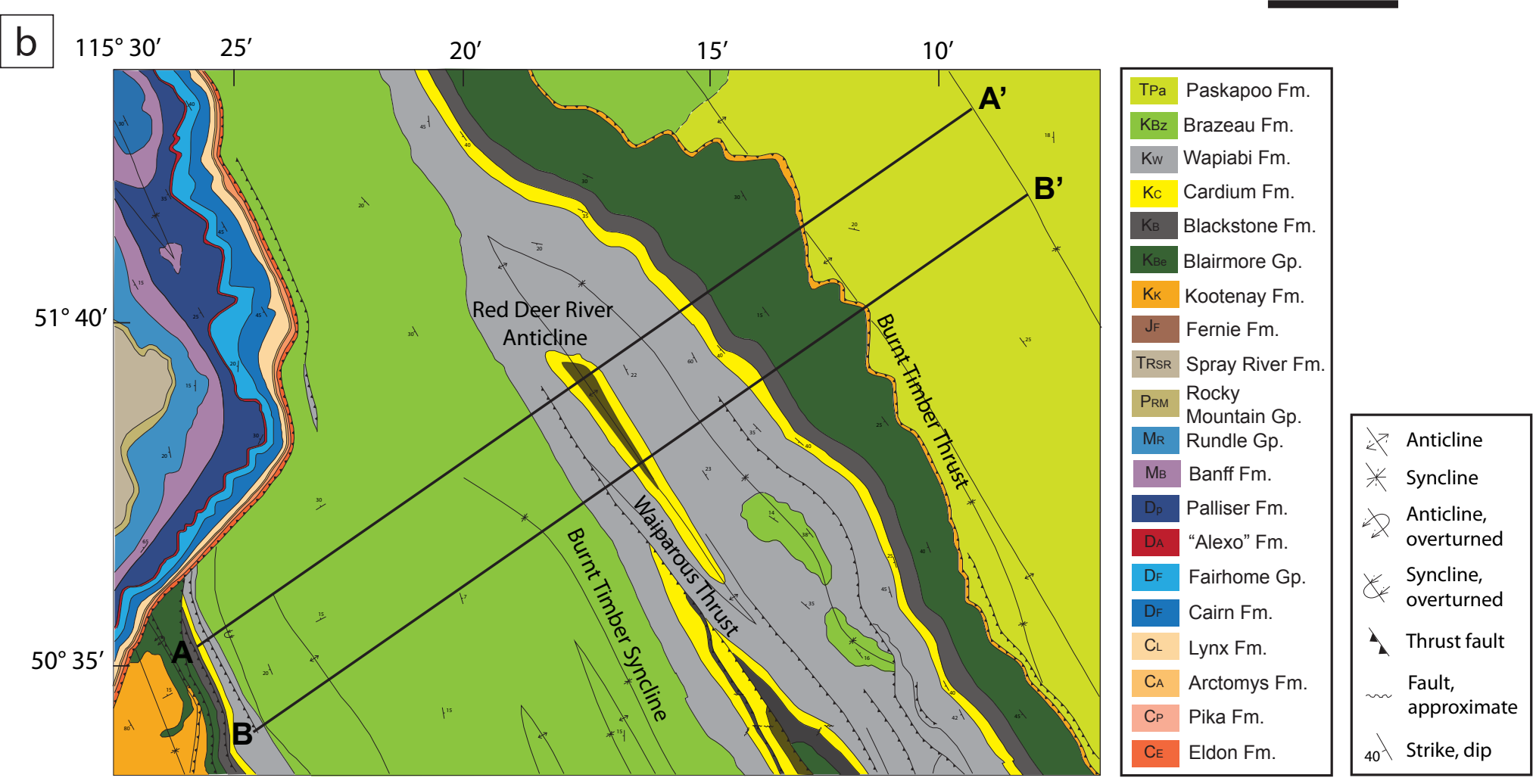




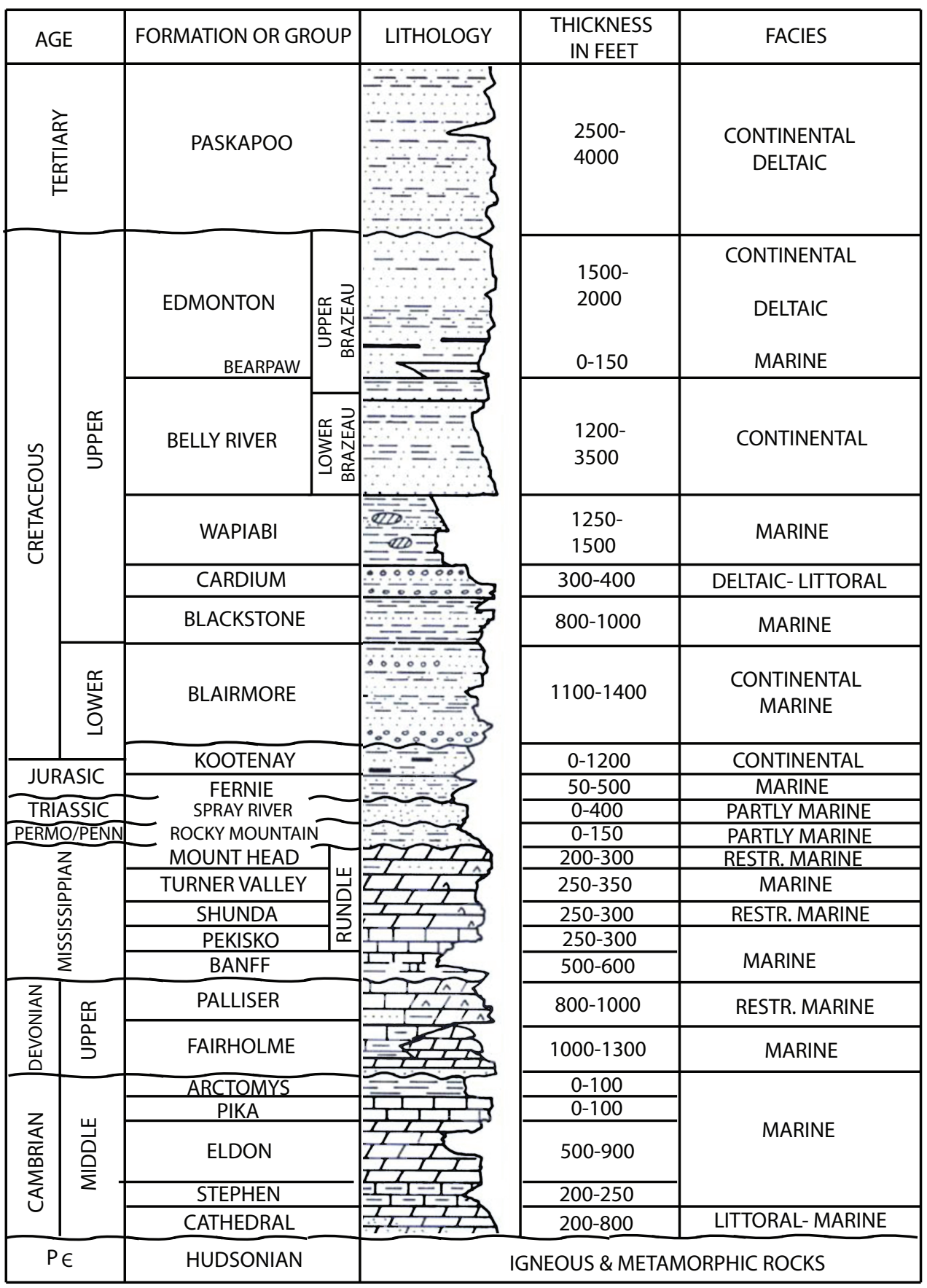

\begin{tabular}{|c|c|}
\hline$\because \because \therefore$ & Conglomerate \\
\hline $\mathrm{O}_{\mathrm{O}} \mathrm{O}_{\mathrm{O}}^{\circ}$ & Sandstone \\
\hline$\therefore$ & Siltsone \\
\hline$\because \because$ & Silty Shale \\
\hline$\overline{\dot{\square}}$ & Sandy Shale \\
\hline$\overline{\bar{E}}$ & Shale \\
\hline & Shaly Limestone \\
\hline $\begin{array}{ll}1,1 \\
\end{array}$ & Limestone \\
\hline$\overline{s-1}$ & Reefal Limestone \\
\hline$\frac{11}{11}$ & Dolomite \\
\hline $1 ! 1$ & Silty Carbonate \\
\hline & Coal \\
\hline (1) & Ironstone Nodules \\
\hline
\end{tabular}

Figure 2 

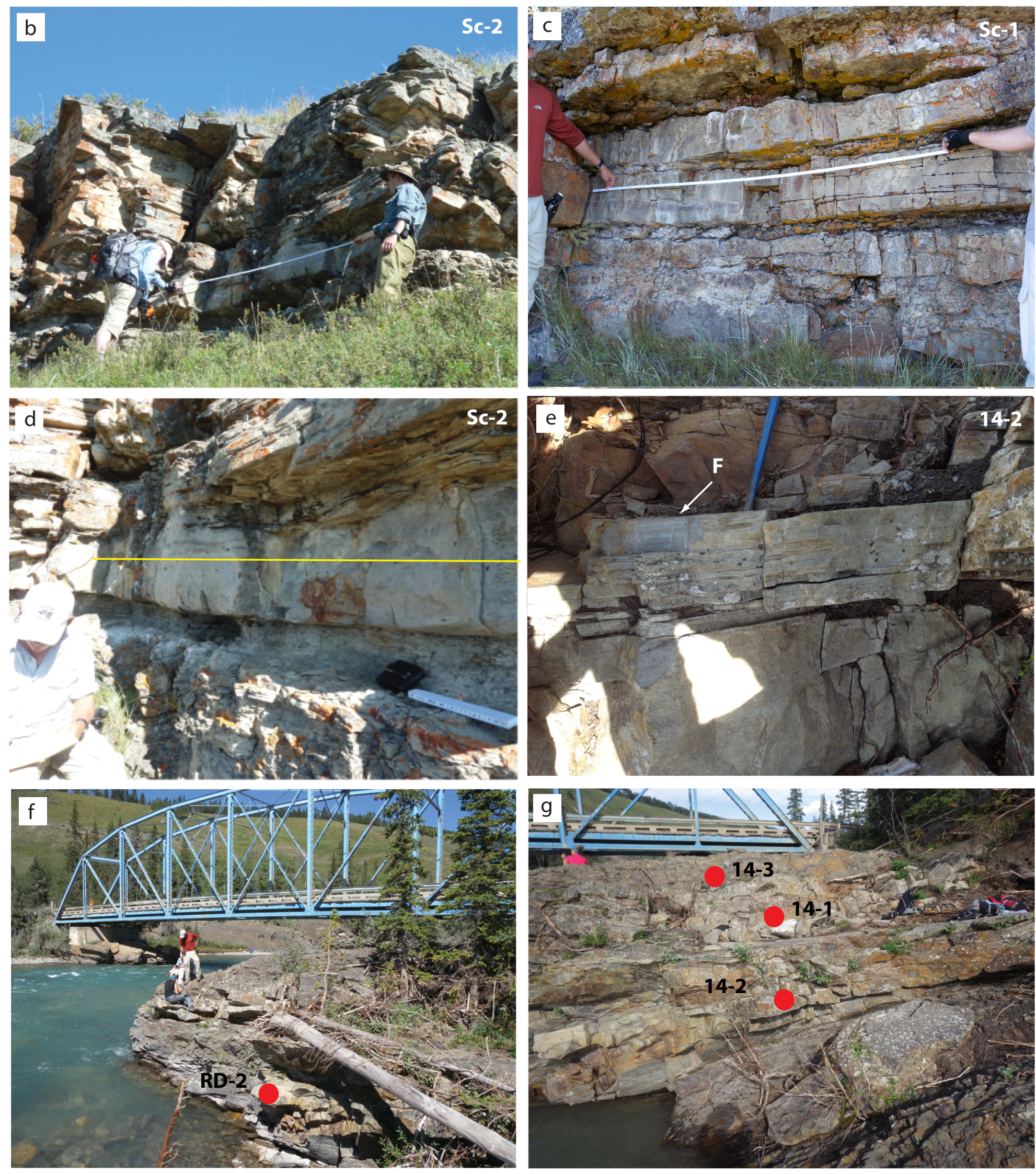

Figure 3 


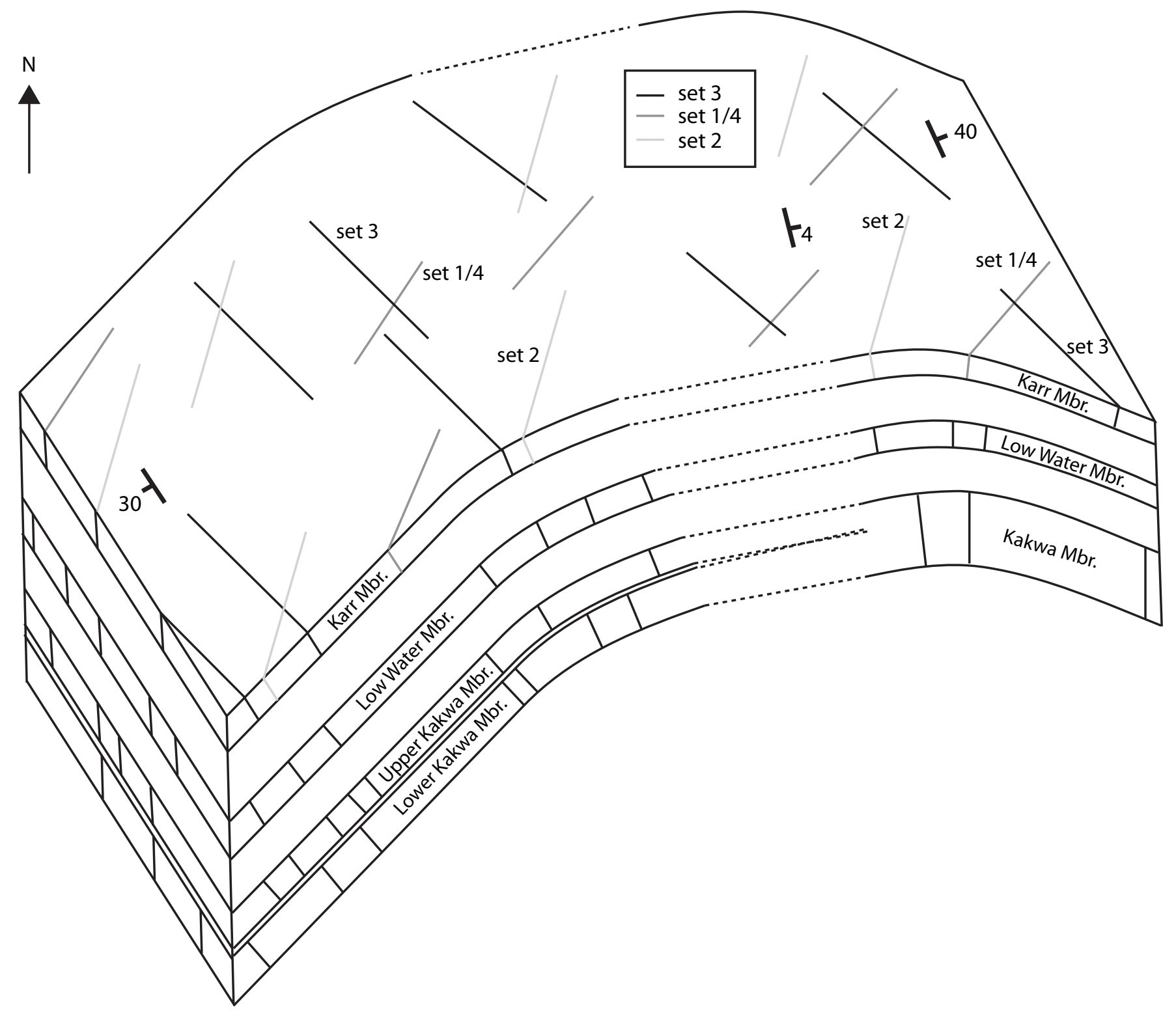

Figure 4 


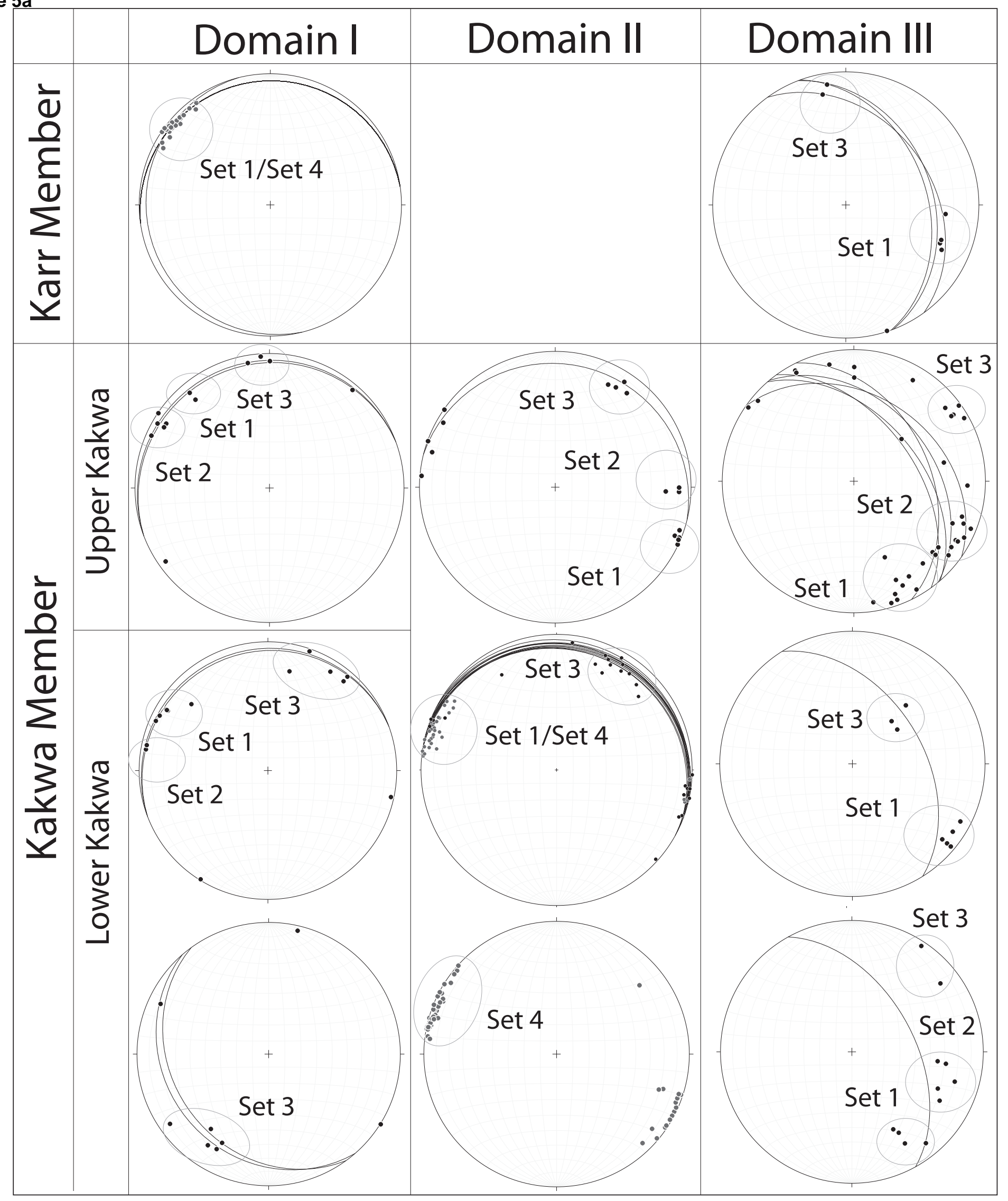

Figure 5a 


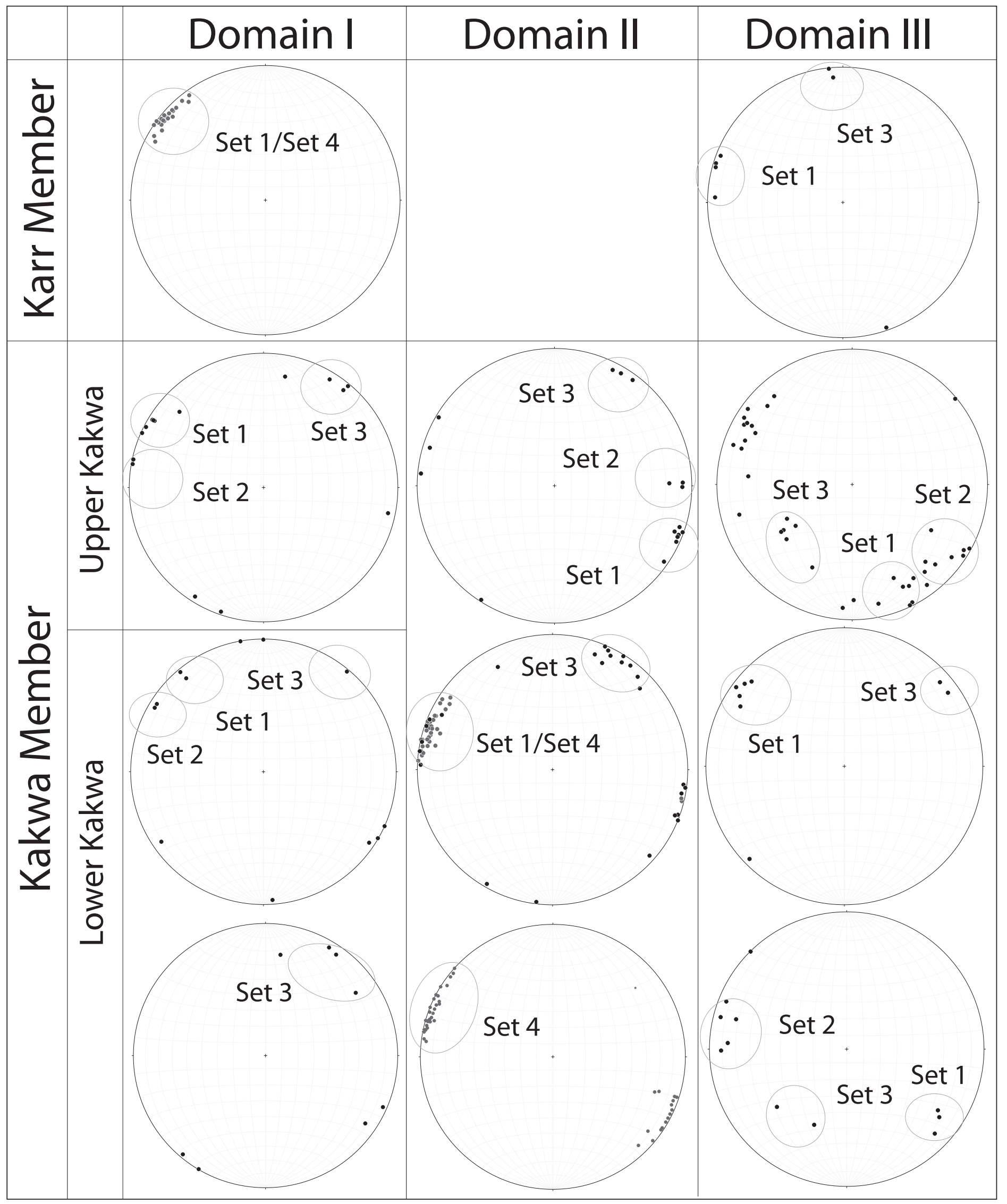

Figure 5b 

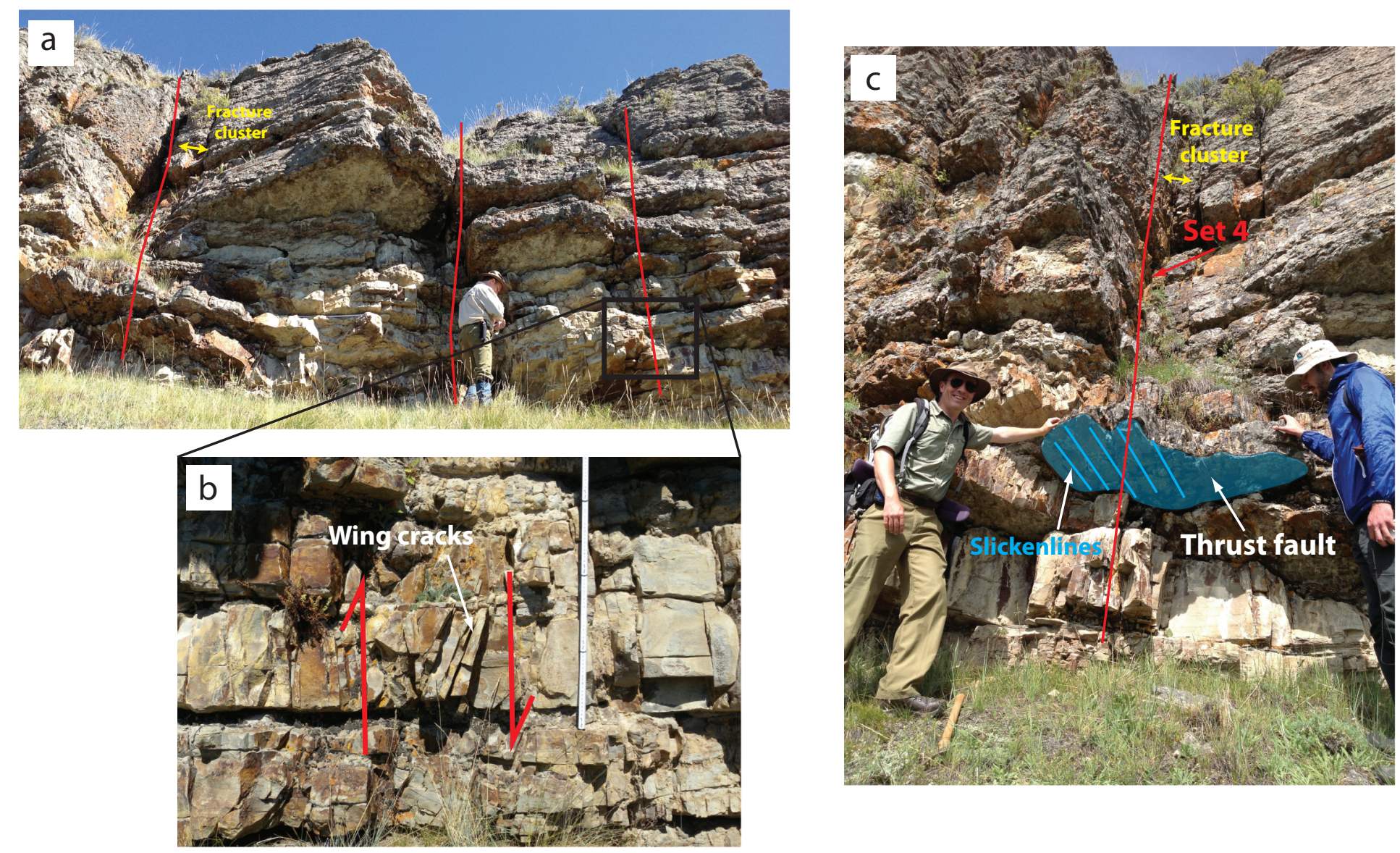

d)

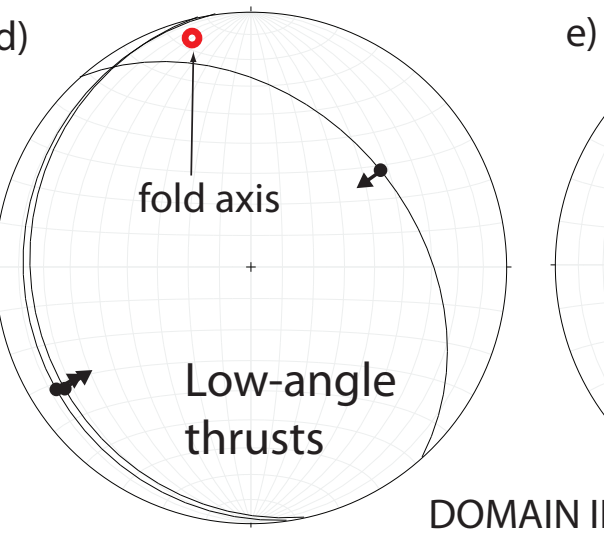

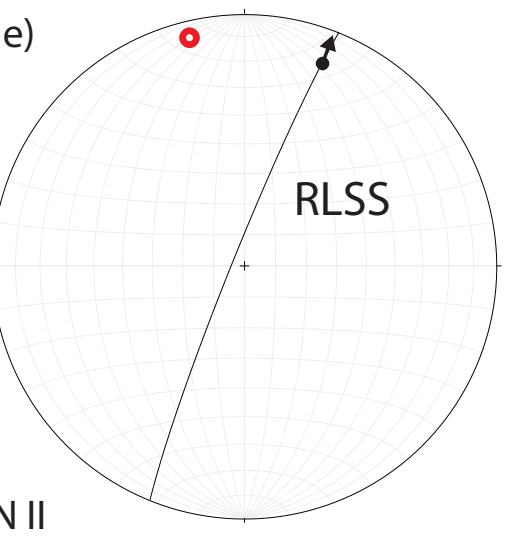

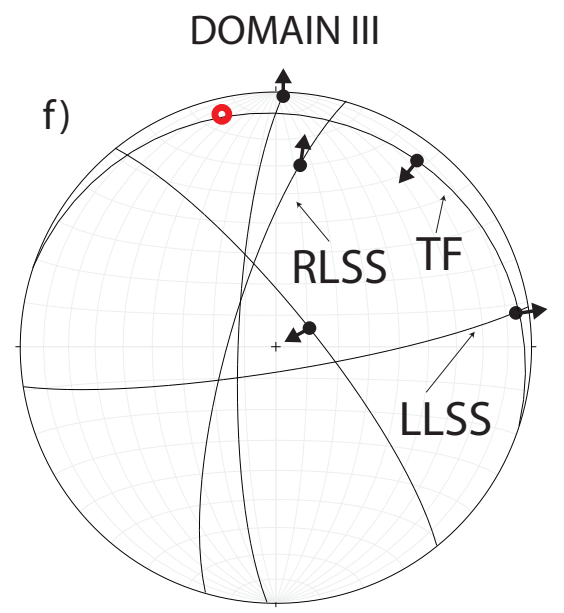

Figure 6 
Figure 7
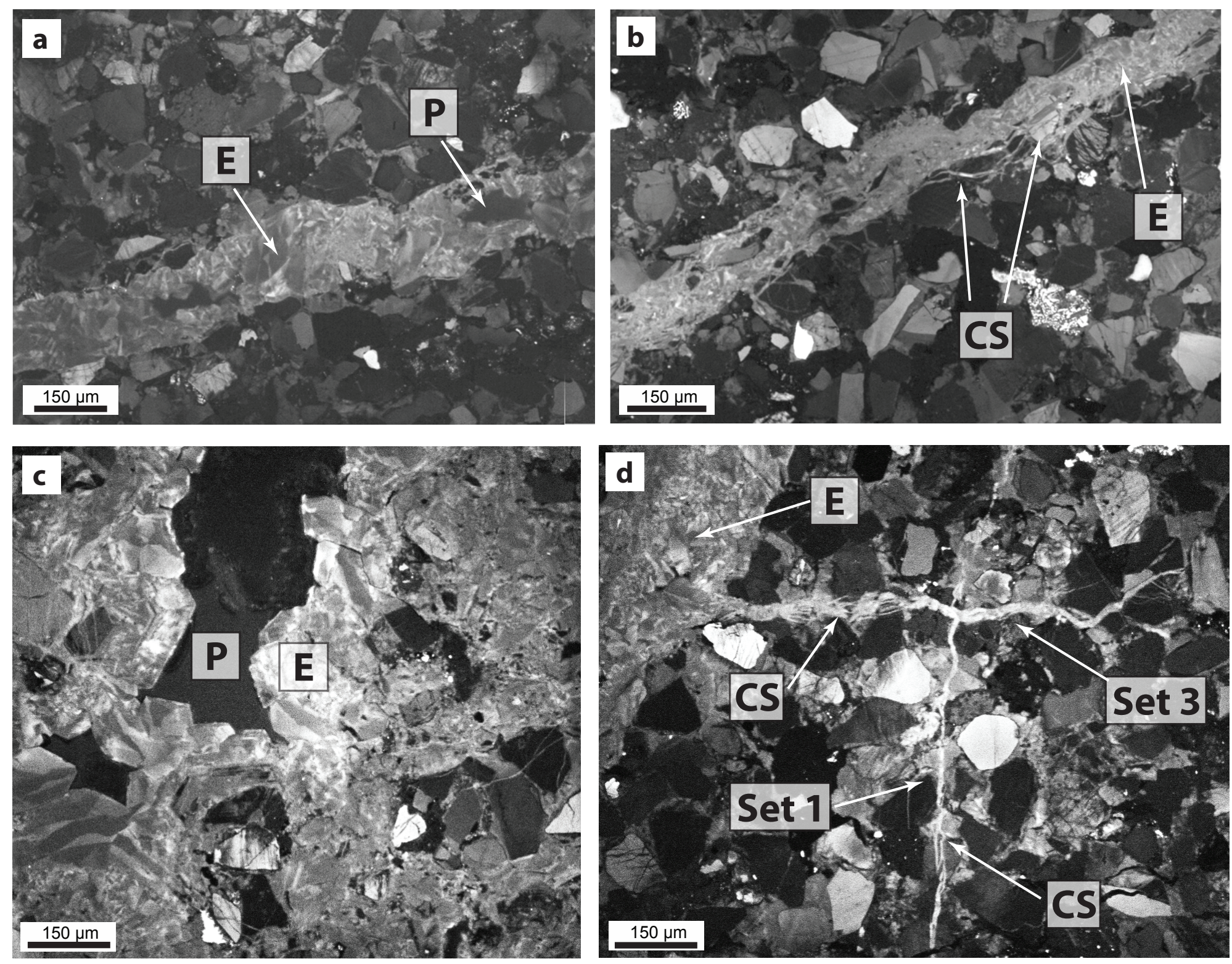

Figure 7 
Figure $8 a$
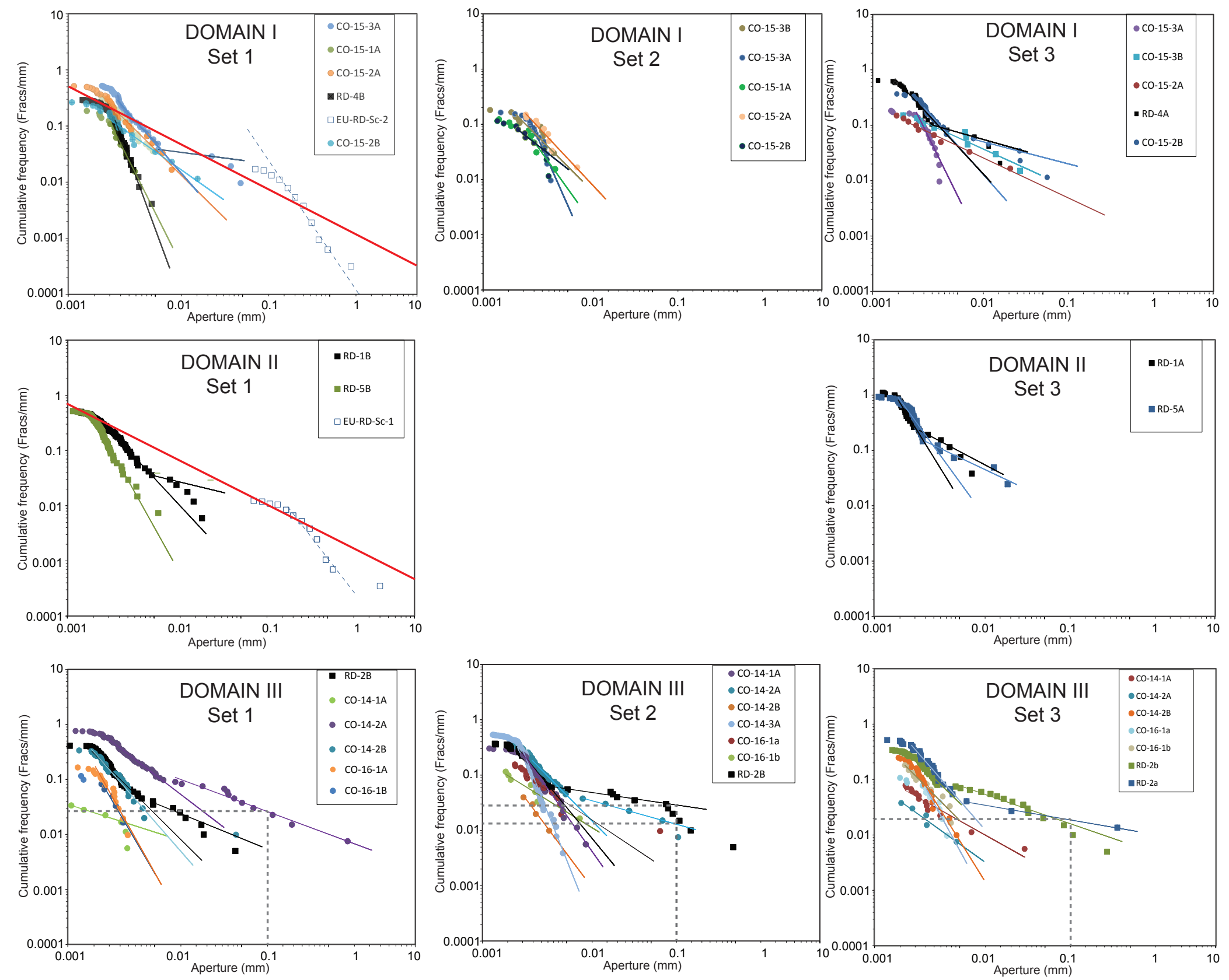

Figure 8a 

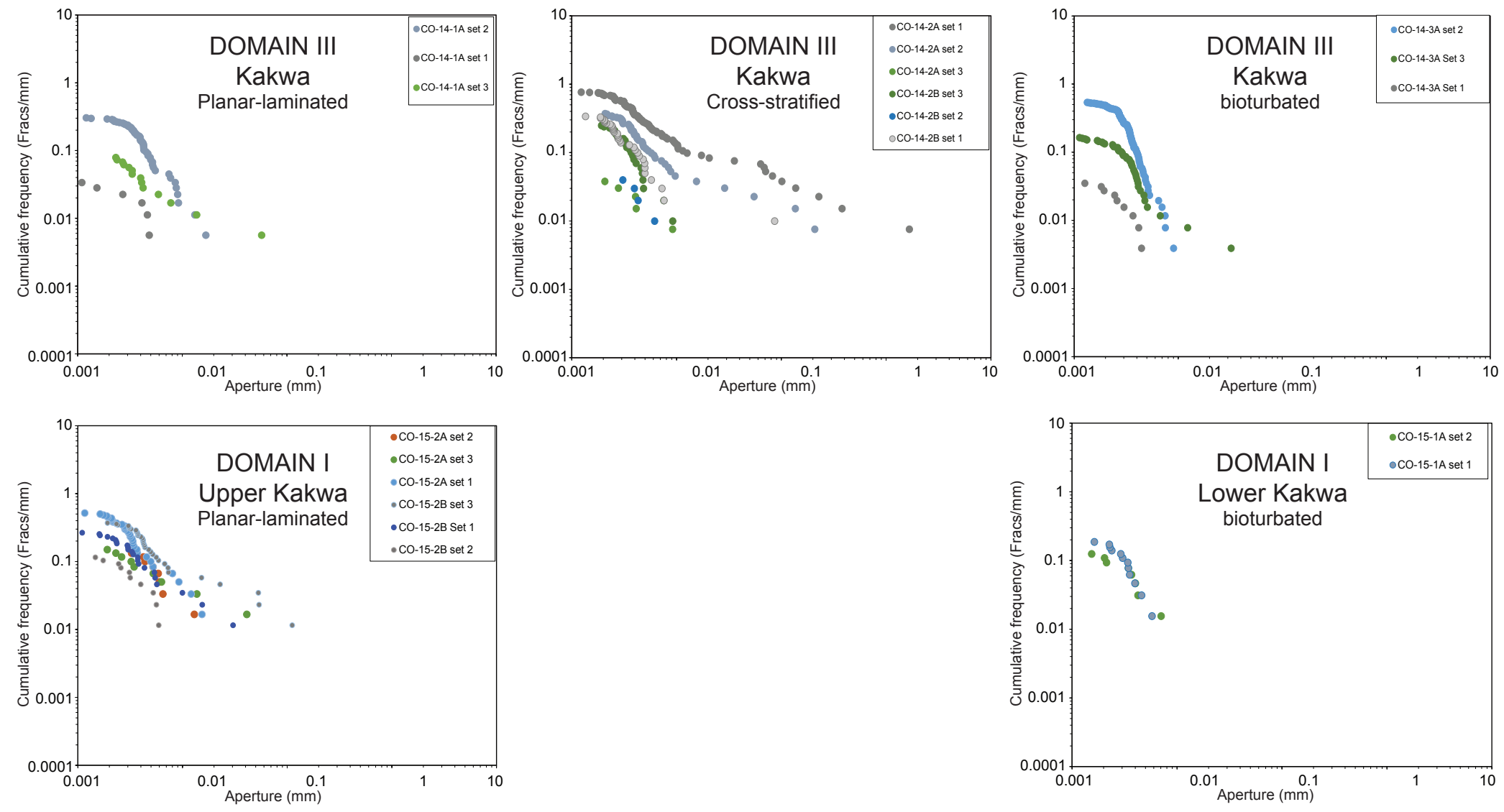

Figure 8b 


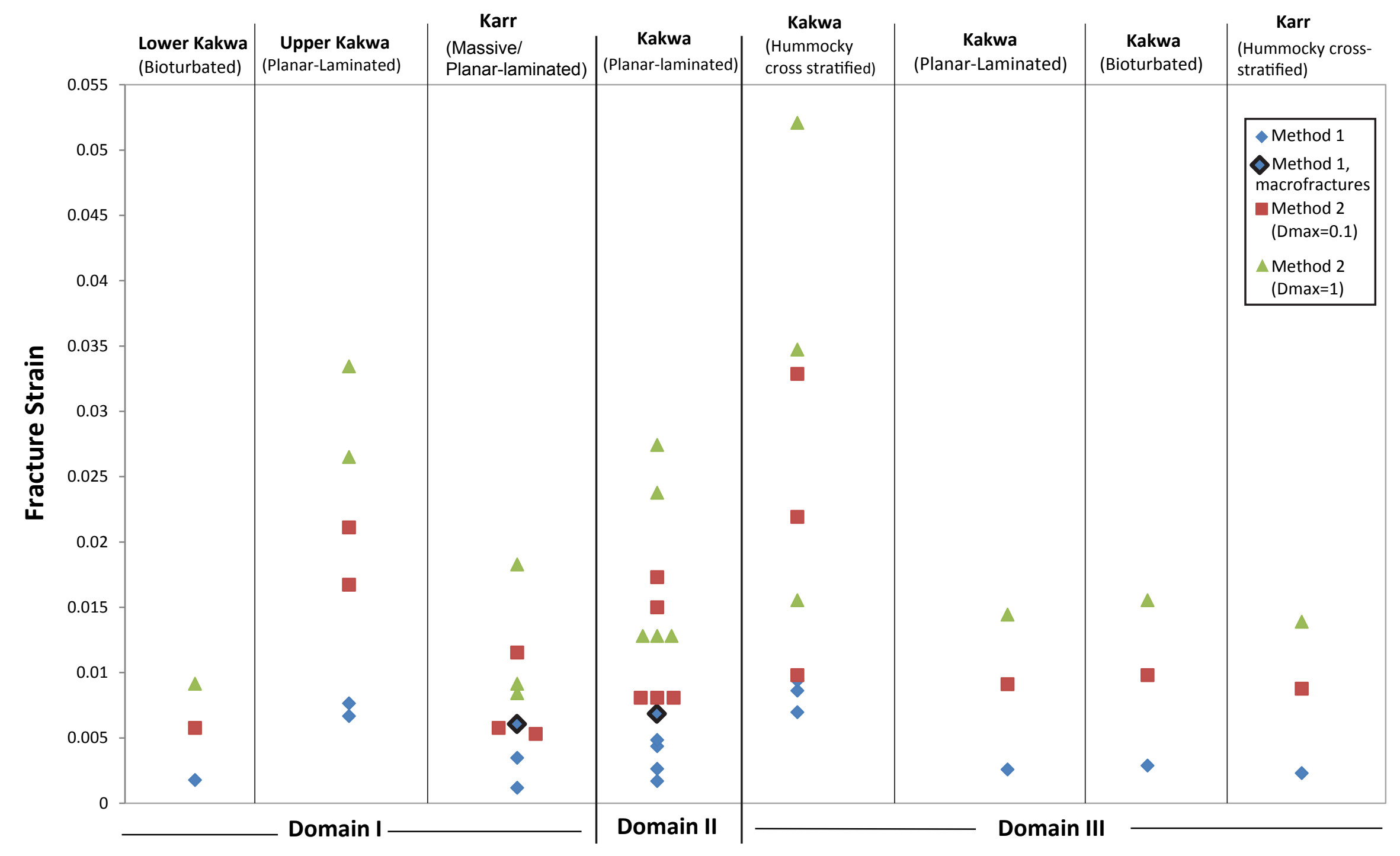

Figure 9 
Figure 10
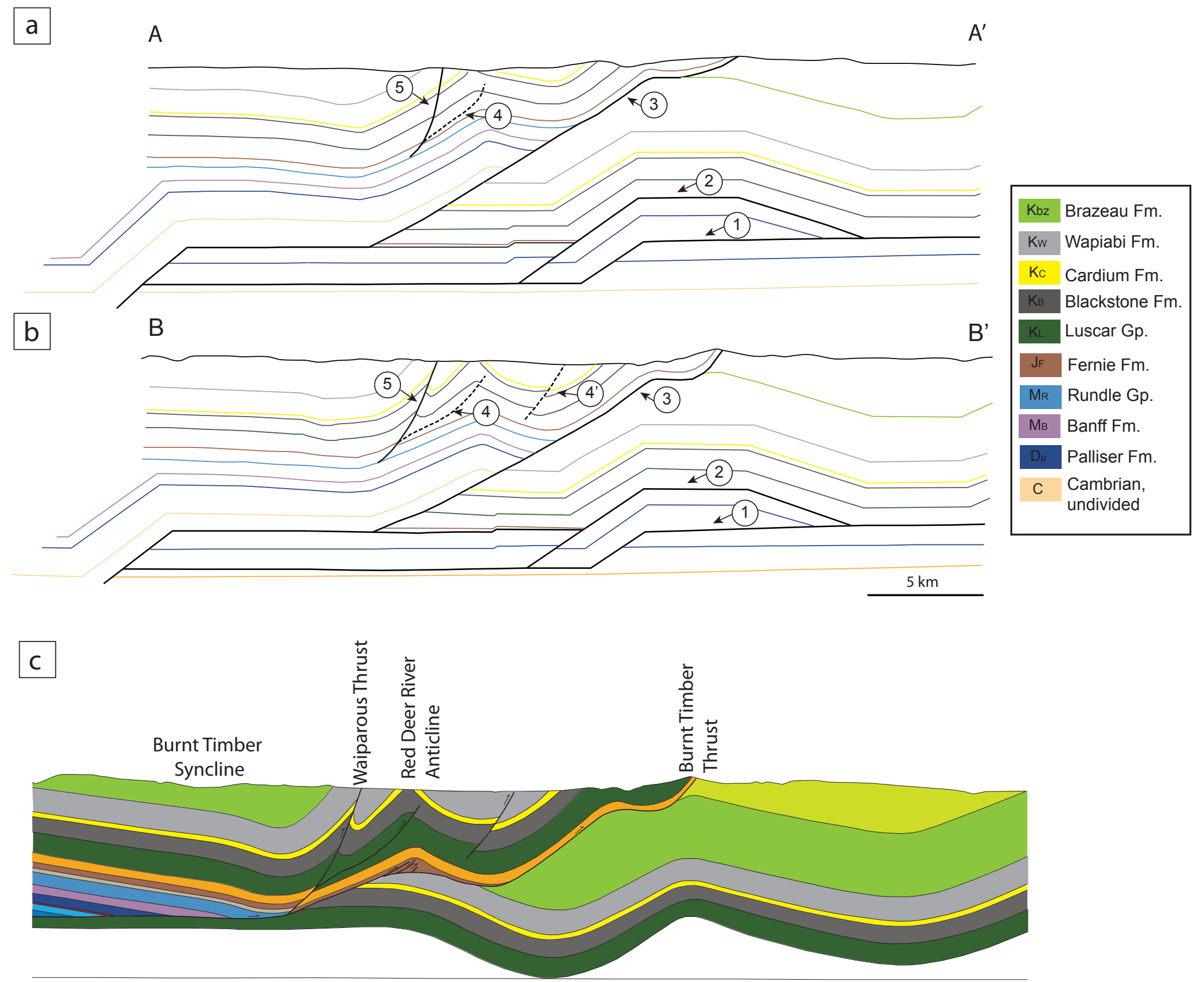

Figure 10 


\section{Top of Cardium Fm.}

a) with exx strain values

\section{(4)}

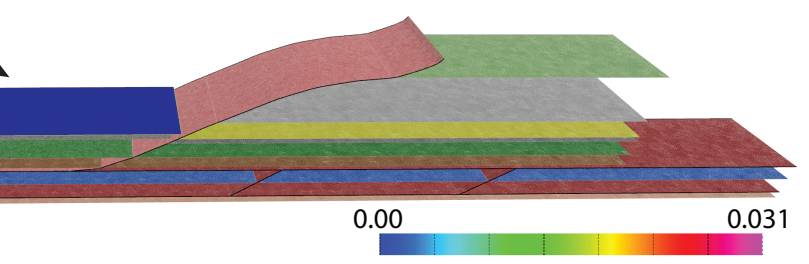

b)

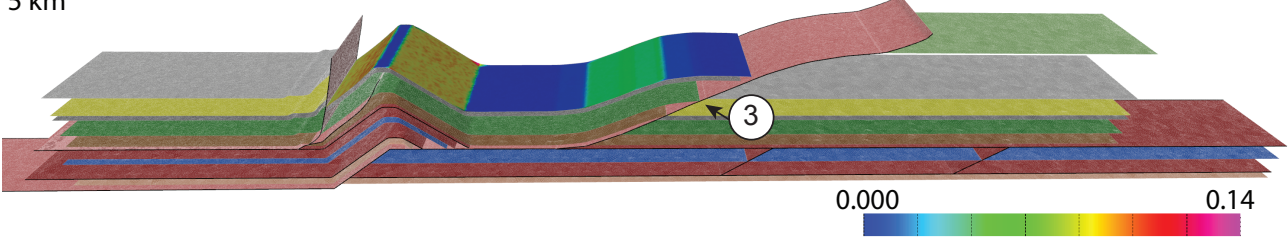

c)

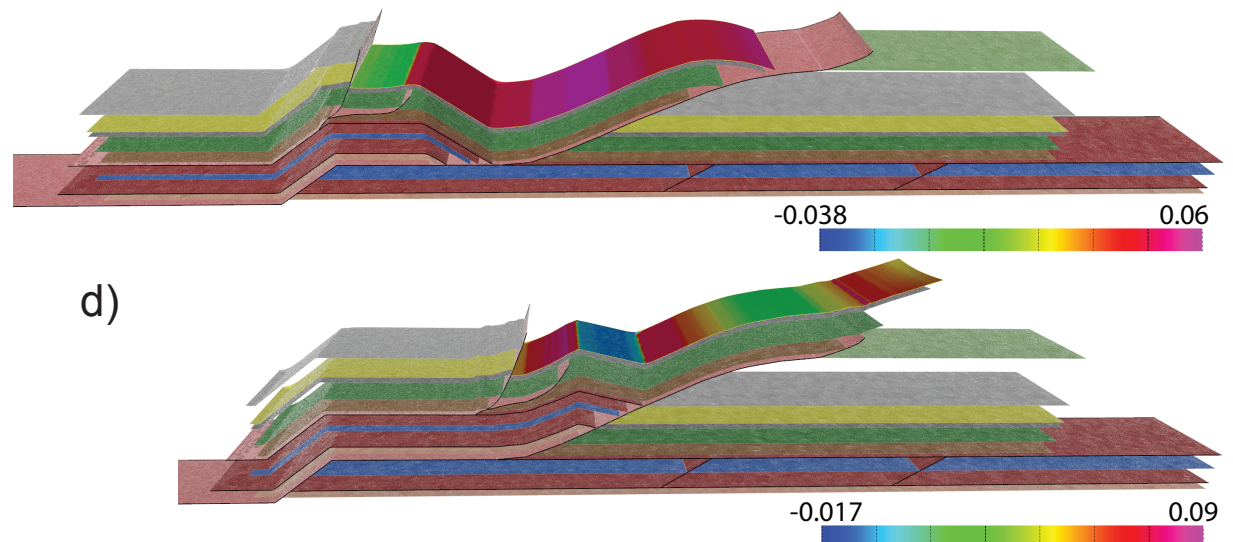

e)

f)

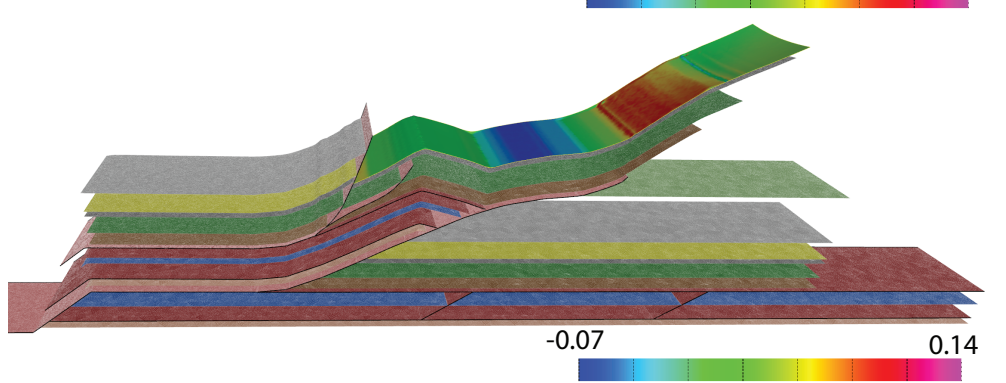

Figure 12

h)

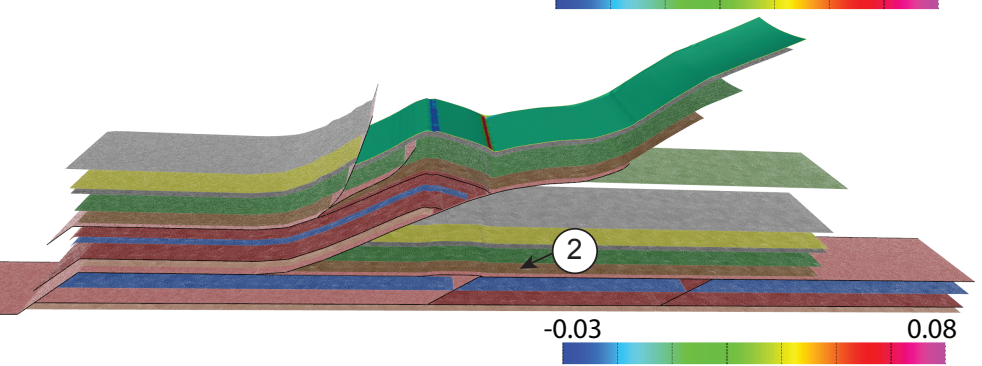

g)
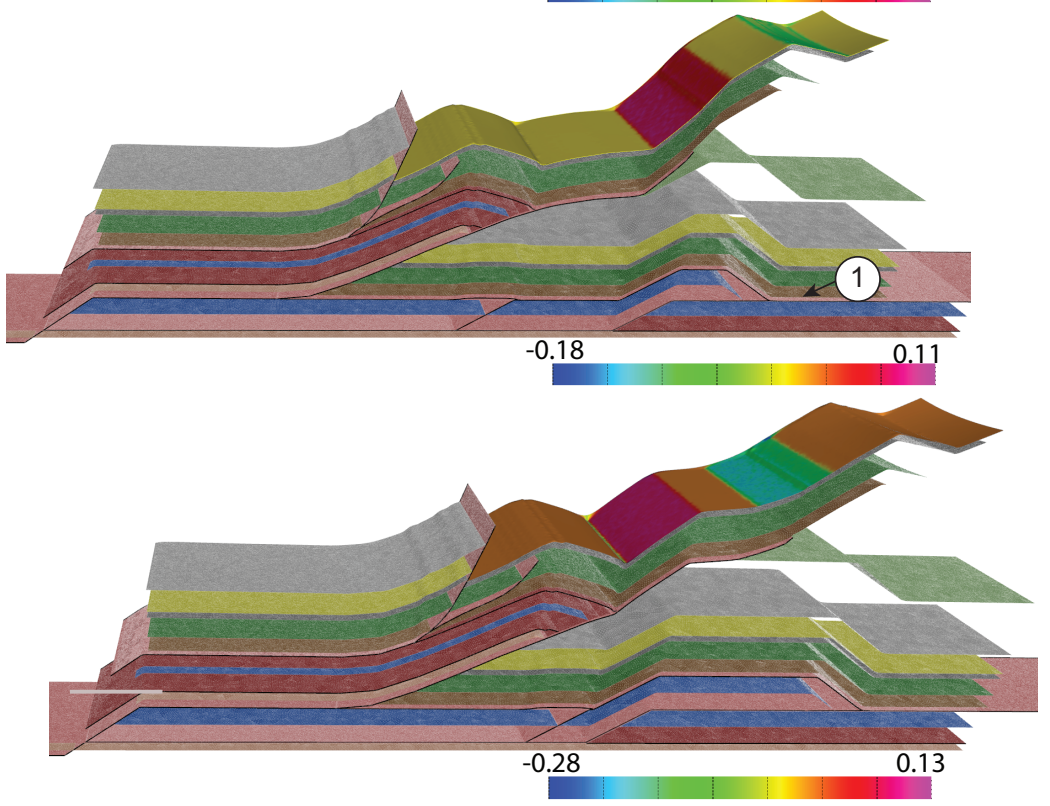
a) with exx strain values

b)

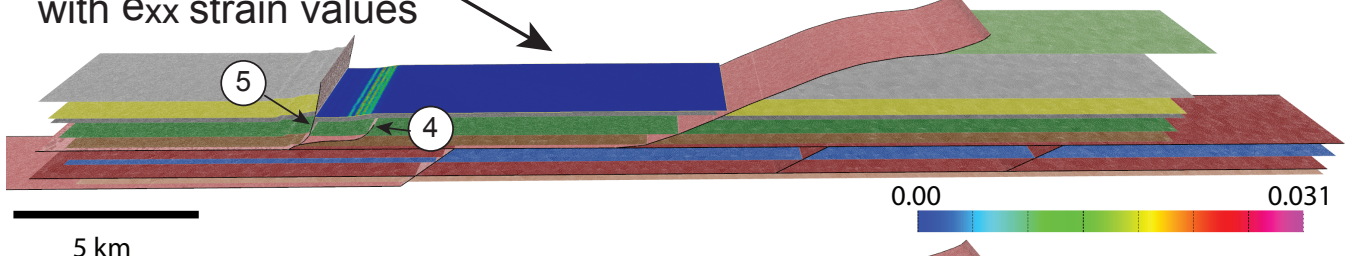

c)

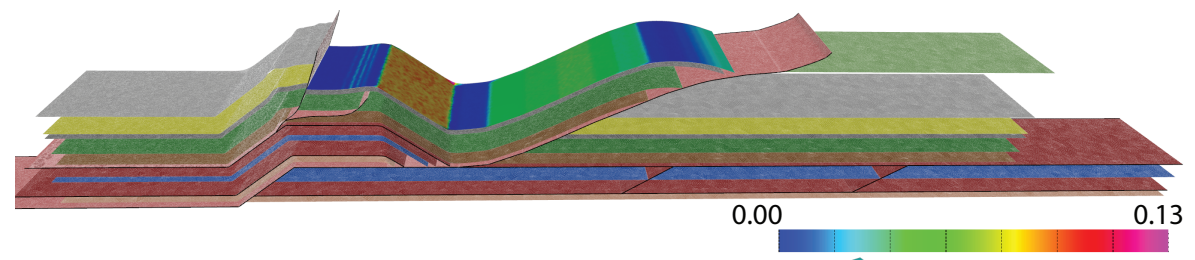

d)

e)

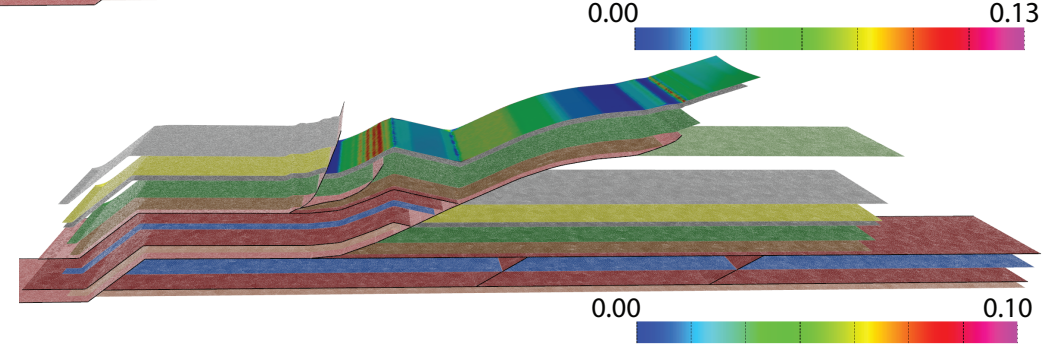

Figure 13

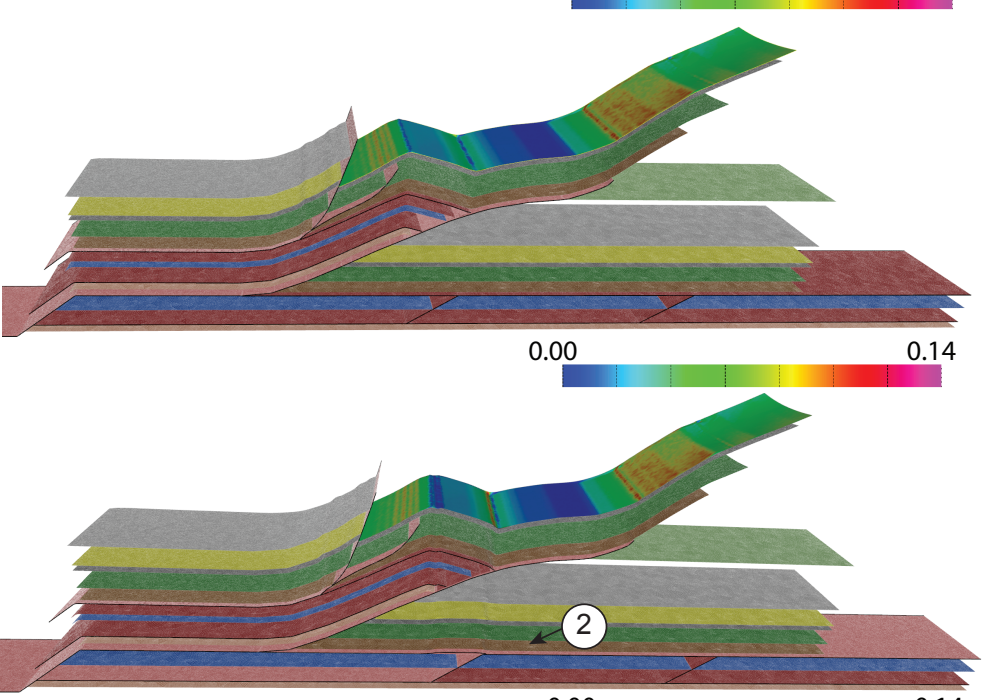

g)

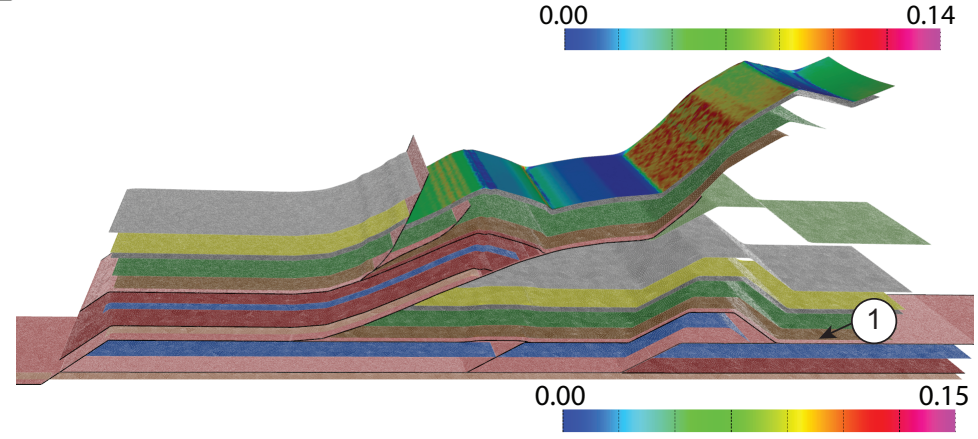

h)

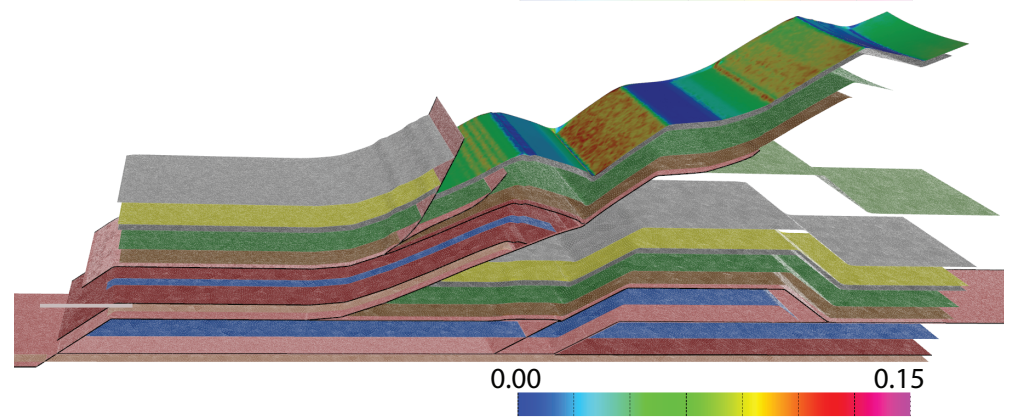


Table 1: General attributes of fracture sets based on data collected in Domain II.

\begin{tabular}{|l|l|l|l|}
\hline Attribute/ Set & Set 1 & Set 2 & Set 3 \\
\hline Strike & NE-SW & N-S & WNW-ESE \\
\hline Strike after unfolding & NE-SW & N-S & WNW-ESE \\
\hline Dip & $\begin{array}{l}\text { Bedding- } \\
\text { perpendicular }\end{array}$ & $\begin{array}{l}\text { Bedding- } \\
\text { perpendicular }\end{array}$ & $\begin{array}{l}\text { Bedding- } \\
\text { perpendicular }\end{array}$ \\
\hline Relative Age & Oldest & $\begin{array}{l}\text { Younger than set } \\
1, \text { older than set 3 }\end{array}$ & $\begin{array}{l}\text { Younger than set 1 } \\
\text { than set 2, older }\end{array}$ \\
\hline Quartz cement & Yes & Yes & Yes \\
\hline $\begin{array}{l}\text { Associated } \\
\text { microfractures }\end{array}$ & Yes & Yes & Yes \\
\hline
\end{tabular}


Table 2: Best-fit equations and $R^{2}$ values of the narrowest and medium-sized mic

\begin{tabular}{|c|c|c|c|}
\hline \multirow{3}{*}{\begin{tabular}{|l|} 
Sample \\
co-15-1a-1 \\
\end{tabular}} & \multirow{3}{*}{\begin{tabular}{|c|} 
Scanline length (mm) \\
64.73 \\
\end{tabular}} & \multicolumn{2}{|r|}{ Micro } \\
\hline & & \multicolumn{2}{|c|}{ narrowest microfractures } \\
\hline & & $y=4 E-07 x^{-2.139}$ & $R^{2}=0.9168$ \\
\hline co-15-2a-1 & 60.37 & $y=1 E-05 x^{-1.635}$ & $R^{2}=0.9371$ \\
\hline co-15-2b-1 & 87.15 & $y=6 E-05 x^{-1.208}$ & $R^{2}=0.969$ \\
\hline co-15-1a-2 & 64.73 & $y=2 E-09 x^{-3.099}$ & $R^{2}=0.9843$ \\
\hline co-15-2a-2 & 60.37 & $y=3 E-05 x^{-1.534}$ & $R^{2}=0.9638$ \\
\hline Rd-4b-all & 244.13 & $y=5 E-12 x^{-4.211}$ & $R^{2}=0.9852$ \\
\hline co-15-2b-2 & 87.15 & $y=0.0002 x^{-1.093}$ & $R^{2}=0.9656$ \\
\hline co-15-2a-3 & 60.37 & $y=0.0015 x^{-0.724}$ & $R^{2}=0.9853$ \\
\hline$c o-15-2 b-3$ & 87.15 & $y=1 E-05 x^{-1.737}$ & $R^{2}=0.9672$ \\
\hline Rd-4a-all & 48.32 & $y=2 E-05 x^{-1.659}$ & $R^{2}=0.9213$ \\
\hline co-15-3b-1 & 66.47 & $y=1 E-05 x^{-1.533}$ & $R^{2}=0.7489$ \\
\hline co-15-3a-1 & 104.14 & $y=4 E-10 x^{-3.454}$ & $R^{2}=0.8848$ \\
\hline co-15-3a-2 & 104.14 & $y=1 E-05 x^{-1.779}$ & $R^{2}=0.9656$ \\
\hline со-15-3a-3 & 104.14 & $y=3 E-09 x^{-3.113}$ & $R^{2}=0.9553$ \\
\hline co-15-3b-3 & 66.47 & $y=0.0024 x^{-0.698}$ & $R^{2}=0.9511$ \\
\hline Rd-1b-all & 168.53 & $y=1 E-05 x^{-1.687}$ & $R^{2}=0.9876$ \\
\hline Rd-5b-all & 136.01 & $y=9 E-09 x^{-2.817}$ & $R^{2}=0.9865$ \\
\hline Rd-1a-all & 26.21 & $y=1 E-07 x^{-2.493}$ & $R^{2}=0.9721$ \\
\hline Rd-5a-all & 40.77 & $y=2 E-06 x^{-2.12}$ & $R^{2}=0.8903$ \\
\hline co-14-1a-1 & 178.88 & $y=9 E-07 x^{-2.157}$ & $R^{2}=0.9799$ \\
\hline co-14-2a-1 & 133.06 & $y=4 E-05 x^{-1.54}$ & $R^{2}=0.9871$ \\
\hline co-14-2b-1 & 101.14 & $y=3 E-07 x^{-2.045}$ & $R^{2}=0.9661$ \\
\hline co-14-3a-1 & 258.35 & $y=7 E-11 x^{-3.816}$ & $R^{2}=0.9832$ \\
\hline co-16-1a-1 & 103.03 & $y=0.0003 x^{-1.016}$ & $R^{2}=0.9835$ \\
\hline co-16-1b-1 & 60.80 & $y=0.0003 x^{-0.944}$ & $R^{2}=0.9381$ \\
\hline Rd-2b-1 & 200.62 & $y=5 E-06 x^{-1.856}$ & $R^{2}=0.9639$ \\
\hline co-14-1a-2 & 178.88 & $y=0.0011 x^{-0.505}$ & $R^{2}=0.9878$ \\
\hline co-14-2a-2 & 133.06 & $y=0.0005 x^{-1.208}$ & $R^{2}=0.9893$ \\
\hline co-14-2b-2 & 101.14 & $y=8 E-09 x^{-2.686}$ & $R^{2}=0.9525$ \\
\hline co-16-1a-2 & 103.03 & $y=5 E-09 x^{-2.826}$ & $R^{2}=0.9089$ \\
\hline co-16-1b-2 & 60.80 & $y=5 E-09 x^{-2.826}$ & $R^{2}=0.9089$ \\
\hline $\mathrm{Rd}-2 \mathrm{~b}-2$ & 200.62 & $y=2 E-05 x^{-1.567}$ & $R^{2}=0.9739$ \\
\hline co-14-1a-3 & 178.88 & $y=0.0003 x^{-0.862}$ & $R^{2}=0.9299$ \\
\hline
\end{tabular}


Table 3:

\begin{tabular}{|l|r|r|r|}
\hline & Strain, Method 1 & \multicolumn{2}{|c|}{ Strain, Method 2 } \\
\hline Scanline & & Dmax = 0.1 $\mathbf{~ m m}$ & Dmax = 1 mm \\
\hline CO-14-1a & 0.0026 & 0.0091 & 0.0144 \\
\hline CO-14-2a & 0.0086 & 0.0329 & 0.0521 \\
\hline CO-14-3a & 0.0029 & 0.0098 & 0.0155 \\
\hline CO-15-1a & 0.0018 & 0.0058 & 0.0091 \\
\hline CO-15-2a & 0.0067 & 0.0167 & 0.0265 \\
\hline CO-15-3a & 0.0076 & 0.0211 & 0.0334 \\
\hline CO-16-1a & 0.0023 & 0.0088 & 0.0139 \\
\hline RD-1A-Sc-all & 0.0044 & 0.0173 & 0.0274 \\
\hline RD-1B-Sc-all & 0.0026 & 0.0081 & 0.0128 \\
\hline RD-2A-Sc-all & 0.0070 & 0.0098 & 0.0155 \\
\hline RD-2B-Sc-all & 0.0094 & 0.0219 & 0.0347 \\
\hline RD-4A-Sc-all & 0.0035 & 0.0115 & 0.0183 \\
\hline RD-4B-Sc-all & 0.0012 & 0.0058 & 0.0091 \\
\hline RD-5A-Sc-all & 0.0048 & 0.0150 & 0.0238 \\
\hline RD-5B-Sc-all & 0.0017 & 0.0081 & 0.0128 \\
\hline EU-Sc-1 ( macro) & 0.0068 & 0.0081 & 0.0128 \\
\hline EU-Sc-2 (macro) & 0.0060 & 0.0053 & 0.0084 \\
\hline
\end{tabular}

